\title{
Contributions of foreign, domestic and natural emissions to US ozone estimated using the path-integral method in CAMx nested within GEOS-Chem
}

\author{
Alan M. Dunker ${ }^{1}$, Bonyoung Koo ${ }^{2}$, and Greg Yarwood ${ }^{2}$ \\ ${ }^{1}$ LLC, 727 Robinhood Circle, Bloomfield Hills, MI 48304, USA \\ ${ }^{2}$ Ramboll Environ, 773 San Marin Dr., Suite 2115, Novato, CA 94945, USA \\ Correspondence to: Alan M. Dunker (alan.m.dunker@gmail.com)
}

Received: 21 April 2017 - Discussion started: 29 May 2017

Revised: 22 August 2017 - Accepted: 12 September 2017 - Published: 24 October 2017

\begin{abstract}
The Goddard Earth Observing System global chemical transport (GEOS-Chem) model was used at $2^{\circ} \times 2.5^{\circ}$ resolution to simulate ozone formation for a base case representing year 2010 and a natural background case without worldwide anthropogenic emissions. These simulations provided boundary concentrations for base and natural background simulations with the Comprehensive Air Quality Model with Extensions (CAMx) on a North American domain (one-way nested) at $12 \mathrm{~km} \times 12 \mathrm{~km}$ resolution over March-September 2010. The predicted maximum daily average $8 \mathrm{~h}$ (MDA8) background ozone for the US is largest in the mountainous areas of Colorado, New Mexico, Arizona, and California. The background MDA8 ozone in some of these locations exceeds $60 \mathrm{ppb}$, when averaged over the 10 days with the largest base-case ozone (T10base average). The background ozone generally becomes both a larger fraction of the base-case ozone in the western US and a smaller fraction in the eastern US when proceeding from spring to summer to the T10base average. The ozone difference between the base and background cases represents the increment to ozone from all anthropogenic sources. The path-integral method was applied to allocate this anthropogenic ozone increment to US anthropogenic emissions, Canadian/Mexican anthropogenic emissions, and the anthropogenic components of the lateral and top boundary concentrations (BCs). Using the T10base average MDA8 ozone, the relative importance of the sources is generally US emissions $>$ anthropogenic lateral BCs $>$ Canadian/Mexican emissions $\gg$ anthropogenic top BCs. Specifically, for 10 US urban areas, the source contributions were $12-53 \mathrm{ppb}$ for US emissions, 3-9 ppb for lateral BCs, $0.2-3$ ppb for Cana-
\end{abstract}

dian/Mexican emissions, and $\leq 0.1 \mathrm{ppb}$ for top BCs. The contributions of the lateral BCs are largest for the higherelevation US sites in the Intermountain West and along the western boundary of the domain. In Denver, for example, the lateral BCs contribute $44 \%$ to the T10base anthropogenic increment. Averaging over the 10 days in the background case with the largest MDA8 ozone (T10bkgd), the contribution from US emissions is reduced to $3-13 \mathrm{ppb}$ at the 10 urban sites, leading to a reduction in the anthropogenic ozone increment. The contribution of the Canadian/Mexican emissions remains about the same $(0.3-2 \mathrm{ppb})$, and the contribution from the lateral BCs increases (5-10 ppb), especially at the lower-elevation urban sites. The net effect at the urban sites is that the relative importance of the anthropogenic lateral BCs is significantly greater for the T10bkgd average than the T10base average. This is also true for rural sites studied, where the anthropogenic lateral BC contribution becomes as large as $68 \%$ of the anthropogenic increment for the T10bkgd average. In addition to the source apportionment, we also used surface and ozonesonde measurements to evaluate GEOS-Chem and CAMx performance.

\section{Introduction}

In 2008, the US Environmental Protection Agency (EPA) reduced the National Ambient Air Quality Standard (NAAQS) for $8 \mathrm{~h}$ ozone $\left(\mathrm{O}_{3}\right)$ to $75 \mathrm{ppb}$ and in October 2015, further reduced the NAAQS to $70 \mathrm{ppb}$. An important consideration is how difficult it will be to meet this standard by reducing 
US emissions alone because anthropogenic emissions outside the US can contribute to US $\mathrm{O}_{3}$. This can occur by the transport of foreign anthropogenic emitted species into the US but more importantly by the transport of $\mathrm{O}_{3}$ and other secondary pollutants formed outside the US from the foreign emissions (Zhang et al., 2008; Jiang et al., 2016; Lin et al., 2017).

Background $\mathrm{O}_{3}$ must be estimated from model simulations, though a related quantity, termed baseline $\mathrm{O}_{3}$, can be estimated from data at relatively remote monitoring sites (Parrish et al., 2012). McDonald-Buller et al. (2011) review background and baseline $\mathrm{O}_{3}$ and how the latter can be used to test model results. There are three common definitions of background $\mathrm{O}_{3}$ : US background, North American background, and natural background, which correspond to elimination of US, North American, or worldwide anthropogenic emissions, respectively (Zhang et al., 2011, 2014; Emery et al., 2012; Fiore et al., 2014; Dolwick et al., 2015; Nopmongcol et al., 2016). The anthropogenic increment of $\mathrm{O}_{3}$ is the difference between a base-case simulation with all emissions present and the chosen type of background simulation. The focus of this work is on the anthropogenic increment over natural background $\mathrm{O}_{3}$.

One approach to apportioning the anthropogenic increment is to remove sources one at a time and determine the change in $\mathrm{O}_{3}$ from the base case (known as the brute-force or zero-out method) (Zhang et al., 2014; Dolwick et al., 2015). A limitation is that the sum of all the anthropogenic source contributions generally does not equal the anthropogenic increment due to the nonlinear chemistry. Another approach is to add reactive tracers (tagged species) to the base case for the emissions from anthropogenic sources and/or the secondary pollutants formed from the emissions and then use the tracers to estimate the contribution of the sources to the total $\mathrm{O}_{3}$ concentration (Zhang et al., 2008; Lefohn et al., 2014; Baker et al., 2015; Dolwick et al., 2015; Nopmongcol et al., 2017). Chemistry causes interactions between the sources through direct and indirect effects. For example, if $\mathrm{O}_{3}$ generated from anthropogenic emissions is transported into the domain through the boundaries, direct effects are destruction of the $\mathrm{O}_{3}$ by reaction with anthropogenic NO emissions in the domain, $\mathrm{O}_{3}+\mathrm{NO} \rightarrow \mathrm{NO}_{2}+\mathrm{O}_{2}$, or reaction with $\mathrm{HO}_{2}$ formed from volatile organic compound (VOC) emissions, $\mathrm{O}_{3}+\mathrm{HO}_{2} \rightarrow \mathrm{OH}+2 \mathrm{O}_{2}$. Indirect effects are the photolysis of the $\mathrm{NO}_{2}$ to recreate $\mathrm{O}_{3}$ and the reaction of the $\mathrm{OH}$ with anthropogenic $\mathrm{VOC}$ emissions to form $\mathrm{O}_{3}$. Reactive tracers can follow some indirect effects (Baker et al., 2015; Nopmongcol et al., 2017) but ultimately it is difficult to follow all the nonlinear chemical interactions among emissions from different sources. In addition, there is no requirement that the sum of tracer contributions ascribed to the anthropogenic sources equals the anthropogenic increment (as defined above). Also, the focus in the tracer approach is solely on the chemistry in the base case. If the chemistry changes significantly from the base to background cases, then an esti- mate of the anthropogenic increment using just the base-case chemistry can have important errors. For example, $\mathrm{O}_{3}$ production per nitrogen oxides $\left(\mathrm{NO}_{x}\right)$ molecule becomes more efficient as $\mathrm{NO}_{x}$ emissions are reduced, and therefore using just the base-case chemistry will very likely underestimate the anthropogenic increment.

The path-integral method (PIM) for source apportionment has the unique capability to allocate the difference in $\mathrm{O}_{3}$ between two simulations (e.g., the anthropogenic increment) to portions of the emissions and boundary concentration (BC) changes between the two simulations such that the sum of the source contributions equals the difference in $\mathrm{O}_{3}$ (Dunker, 2015; Dunker et al., 2015). The PIM determines the source contributions by integrating first-order sensitivity coefficients over the range of emissions from the background case to the base case, and thus the source contributions are not determined just from the chemistry in the base case. Calculating the sensitivity coefficients involves the same Jacobian matrix used in solving the chemical reaction equations. Consequently, the source contributions implicitly include all the direct and indirect effects represented by the chemical mechanism. The PIM does not perturb the model's chemistry and can determine the contributions of all emitted species.

The disadvantage of the PIM is that it requires more computational effort than the brute-force or tracer methods. Compared to brute force, the PIM required 2.7 times more effort in a previous study (Dunker et al., 2015). Tracer methods can be more efficient than both the brute-force method and the PIM as long as relatively few tracers (i.e., fewer tracers than chemical mechanisms have species) are used to perform source apportionment. However, the added effort for PIM provides concentrations (as well as the sensitivities) for multiple emission levels along the control path from the base to background cases, showing how concentrations change as emissions change. Moreover, the PIM can allocate any of the species in the chemical mechanism to the emission sources with only a small incremental effort beyond that needed for $\mathrm{O}_{3}$. Dunker et al. (2015) determined the anthropogenic increments in $\mathrm{O}_{3}$, formaldehyde and $\mathrm{NO}_{2}$ defined by the difference between a base case for 2030 and the US background and allocated the increments to US source categories using the PIM.

For this study, we used the Comprehensive Air Quality Model with Extensions (CAMx; Ramboll-Environ, 2016) in a one-way nest within the Goddard Earth Observing System global chemical transport (GEOS-Chem) model (Bey et al., 2001) to estimate the anthropogenic increment in $\mathrm{O}_{3}$ equal to the difference between a 2010 base case and the natural background. Using the PIM, this increment was then allocated to the US and Canadian/Mexican anthropogenic emissions within the CAMx North American modeling domain and to worldwide anthropogenic emissions outside the domain that impact the CAMx simulation via the BCs. We also conducted an evaluation of the CAMx and GEOS-Chem 
model performance for the base case using various surface and ozonesonde measurements.

\section{Methods}

\subsection{GEOS-Chem simulations}

Two global model simulations were conducted to provide BCs for North American regional model simulations using the latest version of GEOS-Chem available for this work, version 10-01 (http://www.geos-chem.org). The basecase global simulation (G-base) used global anthropogenic emissions from the Emissions Database for Global Atmospheric Research (EDGAR v4.2) (European Commission, 2011) with anthropogenic volatile organic compound (VOC) emissions from the Reanalysis of the Tropospheric chemical composition (RETRO) emission inventory (Reinhart and Millet, 2011). Additional global databases provided anthropogenic emissions from aircraft, ship, fertilizer, and biofuel sources. Regional anthropogenic emission inventories superseded the global emissions for specific regions of the world, e.g., the US, Canada, Mexico, Europe, and Southeast Asia. The natural emissions included biogenic emissions from the Model of Emissions of Gases and Aerosols from Nature (MEGAN) (Guenther et al., 2006), biomass burning from the Global Fire Emissions Database (GFED-3) (Giglio et al., 2010), $\mathrm{NO}_{x}$ from lightning (Murray et al., 2012) and soil (Hudman et al., 2012), volcanic emissions, and wind-blown dust. The second (background) global simulation (G-bkgd) used natural emissions only without any anthropogenic emissions. However, the methane concentration for G-bkgd was the same as for G-base, $\sim 1750 \mathrm{ppb}$ (2007 data), and thus represents the current, not pre-industrial, level.

Both GEOS-Chem simulations were driven by offline meteorological fields generated by the GEOS-5 general circulation model with $2^{\circ}$ latitude $\times 2.5^{\circ}$ longitude horizontal grid resolution and 72 vertical layers (GMAO, 2013). Simulations ran from the beginning of 2009 to the end of 2010 to match the North American regional modeling period (2010). (Year 2009 was the model spinup period.) Table S1 in the Supplement describes the model configuration further, and Tables S2, S3, and S4 give more detail on the global anthropogenic, regional anthropogenic, and natural emission inventories, respectively.

\subsection{CAMx simulations}

CAMx version 6.30 (Ramboll-Environ, 2016) was used to simulate $\mathrm{O}_{3}$ over a North American modeling domain, which covers the continental US and parts of Canada and Mexico with a $12 \mathrm{~km}$ horizontal grid (Fig. 1) and 26 vertical layers. The top boundary is defined by a fixed pressure level, approximately $14-17 \mathrm{~km}$ above ground level, which is generally in the lower stratosphere (Seidel and Randel, 2006). The simulation period covered the $\mathrm{O}_{3}$ season in 2010 (March to

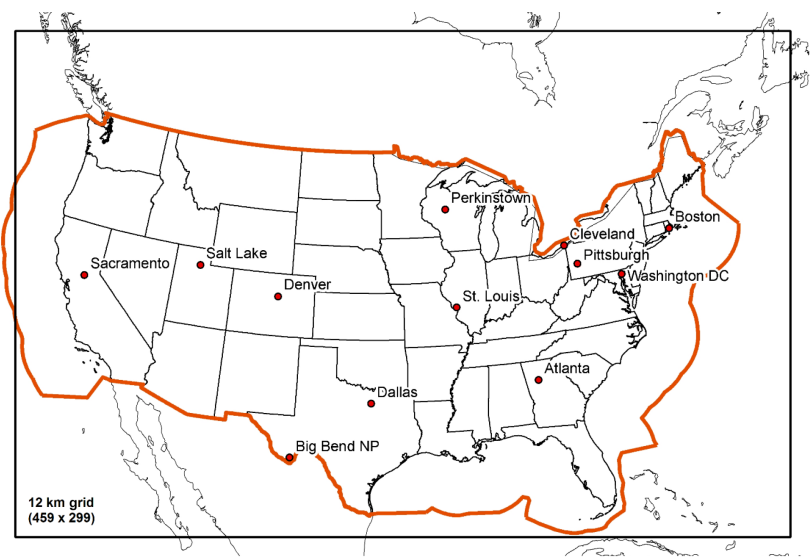

Figure 1. The modeling domain for CAMx showing monitoring sites included in the analysis. The orange line is the US Exclusive Economic Zone. Shipping emissions inside the zone were assigned to the US and outside the zone combined with Canadian and Mexican anthropogenic emissions.

September) with 10 spinup days. For the base-case simulation (NA-base), which included all anthropogenic emissions, BCs were obtained from the G-base simulation with GEOSChem. The background simulation (NA-bkgd) used only natural emissions in the entire domain and BCs from the G-bkgd simulation. Gas-phase chemistry was represented by the Carbon Bond 2005 (CB05) chemical mechanism (Yarwood et al., 2005). Formation of particulates was not included to reduce computational burden and because the focus was on $\mathrm{O}_{3}$.

Anthropogenic and fire emissions were obtained from the 2010 database developed for the Air Quality Model Evaluation International Initiative (AQMEII) phases 2 and 3 (Pouliot et al., 2015). For the US, these emissions were developed by projecting the National Emissions Inventory (NEI) for 2008 (US EPA, 2013) to 2010. We added lightning $\mathrm{NO}_{x}$ emissions using the CAMx lightning emission preprocessor (Koo et al., 2010; Morris et al., 2012). Biogenic emissions, including soil $\mathrm{NO}_{x}$, were estimated using MEGAN with updated land cover data and emission factors (Yu et al., 2015). Canadian and Mexican wildfire emissions are not included in the AQMEII database because spatial and temporal information for these emissions was unavailable (Pouliot et al., 2015). Consequently, contributions of natural emissions in Canada and Mexico to US $\mathrm{O}_{3}$ may be somewhat underestimated in our simulations. However, the absence of the Canadian/Mexican wildfire emissions should have minimal impact on our allocation of the anthropogenic $\mathrm{O}_{3}$ increment to the anthropogenic Canadian/Mexican emissions. A summary of the emissions is in Table 1, divided into the contributions from the US and the remainder of the CAMx domain.

Meteorological conditions and other auxiliary model inputs are also from the AQMEII modeling database. The meteorological fields are from a simulation for 2010 with the Weather Research and Forecasting (WRF) model (Ska- 
Table 1. Average daily emissions in the CAMx modeling domain for March-September 2010.

\begin{tabular}{lrrrrrrr}
\hline Source & \multicolumn{3}{c}{$\begin{array}{c}\text { US emissions } \\
\left(\mathrm{tday}^{-1}\right)\end{array}$} & & \multicolumn{3}{c}{$\begin{array}{c}\text { Canadian/Mexican emissions } \\
\left(\mathrm{tday}^{-1}\right)\end{array}$} \\
\cline { 2 - 3 } \cline { 8 - 9 } & $\mathrm{NO}_{x}$ & $\mathrm{VOC}$ & $\mathrm{CO}$ & & $\mathrm{NO}_{x}$ & $\mathrm{VOC}$ & $\mathrm{CO}$ \\
\hline Anthropogenic (inland) & 41206 & 31194 & 139750 & & 7377 & 7596 & 26874 \\
Shipping & 1927 & 61 & 163 & & 1290 & 40 & 106 \\
Fires & 559 & 6054 & 37851 & & & & \\
Lightning & 5983 & & & & 4577 & & \\
Biogenic & 1634 & 125249 & 18092 & & 717 & 47471 & 4810 \\
Total & 51308 & 162557 & 195855 & & 13961 & 55107 & 31790 \\
\hline
\end{tabular}

marock et al., 2008) conducted by the US EPA as part of AQMEII.

\subsection{Source apportionment by PIM}

The PIM determines the source contributions by integrating first-order sensitivity coefficients over a range of emissions from the background case to the base case (Dunker, 2015). The equation relating the anthropogenic increment to the source contributions is

$$
\begin{aligned}
c_{i}^{\text {base }}(\boldsymbol{x}, t ; \boldsymbol{\Lambda} & =1)-c_{i}^{\mathrm{bkgd}}(\boldsymbol{x}, t ; \boldsymbol{\Lambda}=0) \\
& =\sum_{m=1}^{M} \int_{P} \frac{\partial c_{i}(\boldsymbol{x}, t ; \boldsymbol{\Lambda})}{\partial \lambda_{m}} d \lambda_{m} .
\end{aligned}
$$

Here, $c_{i}^{\text {base }}$ is the concentration of species $i$ in the base simulation at location $\boldsymbol{x}$ and time $t, c_{i}^{\mathrm{bkgd}}$ is the concentration in the background simulation, $M$ is the number of sources, and $\left.\partial c_{i}(\boldsymbol{x}, t ; \boldsymbol{\Lambda})\right) / \partial \lambda_{m}$ is the sensitivity of $c_{i}$ to the parameter $\lambda_{m}$. The vector $\boldsymbol{\Lambda}$ contains the parameters $\lambda_{m}, m=1$, ... M. Each $\lambda_{m}$ scales the difference in emissions or BCs between the base and background cases such that when all $\lambda_{m}=0$ (i.e., $\boldsymbol{\Lambda}=0$ ) we have the background case and when all $\lambda_{m}=1(\boldsymbol{\Lambda}=1)$ we have the base case. $P$ is some path from $\boldsymbol{\Lambda}=0$ to $\boldsymbol{\Lambda}=1$, which is not necessarily a straight line. The source contributions are the integrals on the right side of Eq. (1), and, as indicated, the sum of the source contributions is mathematically required to equal the difference between the base and background concentrations.

In the integration direction of Eq. (1), emissions increase along the path as the $\lambda_{m}$ increase, and the integrals accumulate the contributions to $\mathrm{O}_{3}$ from the sources due to the added emissions. Viewed in reverse, the path is a scenario for reducing emissions from the base case to achieve the background case. We chose a path on which all emissions are reduced by the same factor (a synchronous or diagonal path, represented by $\left.\lambda_{m}=\lambda, m=1, \ldots M\right)$. This assumes that future controls on anthropogenic emissions will produce similar fractional reductions in different regions and for different species. A different path could be chosen for the integration based on detailed projections of future emission controls in the US,
Canada, Mexico, and countries outside the modeling domain. At least in the US, regulators have generally chosen to reduce all precursors of $\mathrm{O}_{3}$ by similar fractions; e.g., from 1990 to 2015 emissions of $\mathrm{NO}_{x}, \mathrm{VOCs}$, and $\mathrm{CO}$ were reduced by 54, 41, and $65 \%$, respectively (US EPA, 2017). Thus, our assumption on controls, though simple, is reasonably consistent with long-term US history. Significant additional work would be necessary to create a more detailed control path for all the countries.

For this work, we divided the anthropogenic increment to $\mathrm{US}_{3}$ into four source contributions $(M=4)$ : (1) US anthropogenic emissions in the CAMx domain; (2) Canadian/Mexican anthropogenic emissions in the domain; (3) the anthropogenic component of the lateral BCs; and (4) the anthropogenic component of the top BCs. Together, the four sources account for the impact of all anthropogenic emissions, worldwide, on the US $\mathrm{O}_{3}$. Regarding the first two sources, we separated shipping emissions within the CAMx domain into emissions inside and outside the US Exclusive Economic Zone (NOAA, 2016a), generally a 200 nautical mile limit of the coast (Fig. 1). Emissions inside the limit were assigned to the US and outside the limit to the Canadian/Mexican category. The latter two sources represent pollutants from outside the domain that arrive through the boundaries, both primary anthropogenic emitted species and secondary pollutants, e.g., $\mathrm{O}_{3}$, formed from the emitted species. The anthropogenic component of the BCs is determined by the difference in BCs between the base and background cases.

Anthropogenic species emitted within the CAMx domain and secondary pollutants resulting from them may move outside the domain and then recirculate back into the domain. The PIM includes this effect via the anthropogenic component of the BCs, to the extent that GEOS-Chem has similar emissions, circulation patterns, and chemistry as CAMx within the CAMx domain. In our calculations, the impact of such recirculation of anthropogenic pollutants will be ascribed to the BCs rather than to anthropogenic emissions from the US or Canada/Mexico. If the PIM were used with a single global model, the impact of the US anthropogenic emissions would be ascribed to the US, regardless of where 


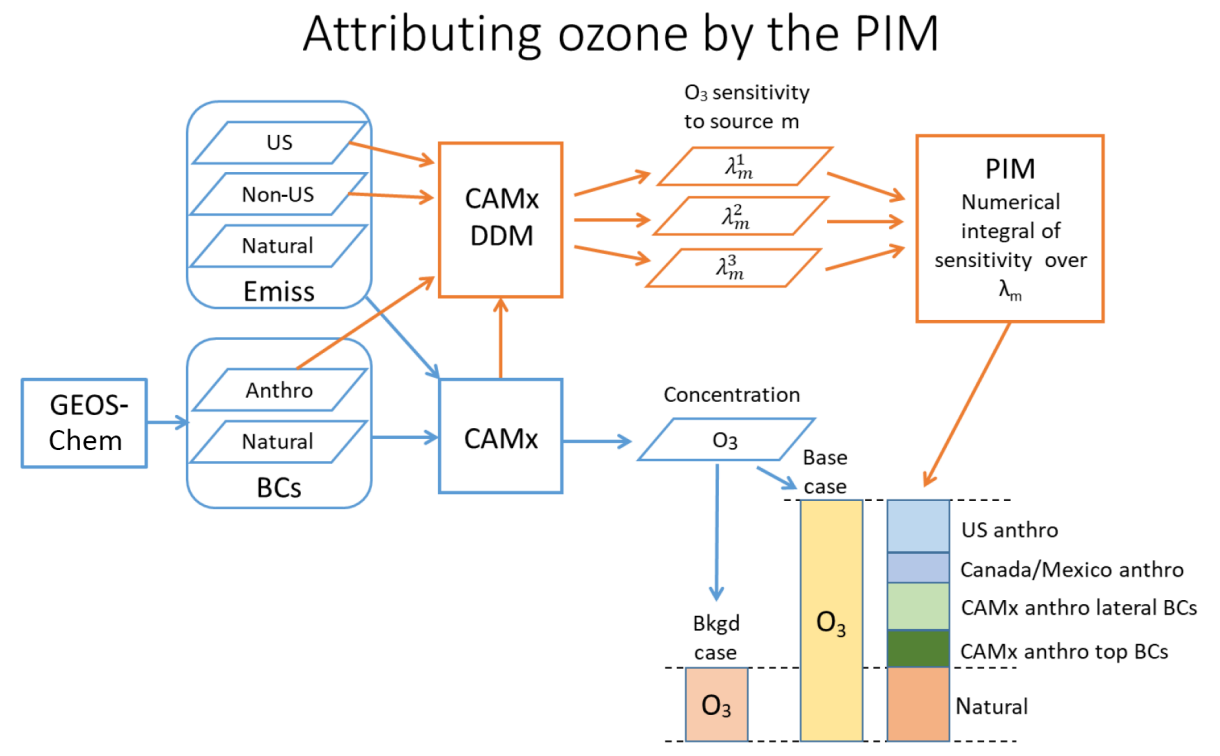

Figure 2. Schematic diagram of source apportionment by the path-integral method (PIM). Two worldwide GEOS-Chem simulations with and without anthropogenic emissions provide boundary concentrations (BCs) for the corresponding CAMx simulations. Two CAMx simulations with and without anthropogenic emissions give the base and background cases for North America. Three CAMx simulations using the decoupled direct method (DDM) provide the $\mathrm{O}_{3}$ sensitivity to source category $m$ for emissions and BCs scaled between the base and background cases by factors $\lambda_{m}^{1}, \lambda_{m}^{2}$, and $\lambda_{m}^{3}$. Numerical integration using the sensitivities at $\lambda_{m}^{1}, \lambda_{m}^{2}$, and $\lambda_{m}^{3}$ gives the contribution of source $m$ to the anthropogenic increment to $\mathrm{O}_{3}$ (base minus background cases). Blue boxes and arrows indicate information flow for CAMx; orange boxes and arrows indicate information flow for the PIM.

the US emitted species and secondary pollutants are transported. Current tracer methods used in regional models (e.g., Ozone Source Apportionment Technology; Yarwood et al., 1996; Ramboll-Environ, 2016) estimate the contribution of the total BCs but do not separate out the contribution of anthropogenic pollutants arriving via the boundaries. The brute-force method could estimate the contribution of anthropogenic pollutants entering from the boundaries by difference between two simulations with different BCs, i.e., derived from global model simulations with and without anthropogenic emissions.

Equation (1) is an exact mathematical relationship, but in an application the integration must be done numerically. We used a Gauss-Legendre formula with three points (Mathews and Fink, 2004) and transformed the integration variable from $\lambda$ to $r=\lambda^{0.5}$ to improve accuracy. The sensitivities were calculated at the three points (different levels of emissions and BCs) by the decoupled direct method (DDM) (Dunker, 1984; Yang et al., 1997; Dunker et al., 2002). Additional details of the PIM are in Dunker (2015) and Dunker et al. (2015). Figure 2 illustrates schematically the relationship of the PIM to the GEOS-Chem and CAMx simulations.

\section{Results}

\subsection{Model performance for GEOS-Chem}

We evaluated modeled $\mathrm{O}_{3}$ from the G-base simulation at selected surface sites outside the US: one site in Ireland, four sites in Japan, and five sites in Canada (WMO, 2016). The site in Ireland (Mace Head) is influenced by outflow transport across the Atlantic Ocean from North America. The Japanese sites experience $\mathrm{O}_{3}$ export from continental Asia to the Pacific Ocean, and the five rural sites in Canada are near the northern boundary of the CAMx modeling domain. For averages over March-September using a $40 \mathrm{ppb}$ threshold, GEOS-Chem underestimated $\mathrm{O}_{3}$ at all the selected sites except for Kejimkujik in Nova Scotia, which is influenced by US outflow (Table 2). With no threshold, GEOS-Chem overpredicted $\mathrm{O}_{3}$ at all sites except Mace Head. Thus, GEOSChem has less dynamic range than observations and tends to underestimate the larger surface $\mathrm{O}_{3}$ concentrations outside the CAMx domain but overestimate the lower concentrations. With the $40 \mathrm{ppb}$ threshold, the normalized mean error is $13-28 \%$. The error and the correlation are both generally greater with no threshold.

Vertical $\mathrm{O}_{3}$ profiles were compared to ozonesonde measurements (NOAA, 2016b) at Trinidad Head, CA; Hilo, HI; Boulder, CO; Huntsville, AL; Narragansett, RI; Summit, Greenland; and the South Pole (Table S5). Figure 3 shows the comparisons for Trinidad Head and Hilo in April and 
Table 2. Model performance metrics for hourly $\mathrm{O}_{3}$ from the GEOS-Chem base case for the March-September 2010 period with zero or $40 \mathrm{ppb}$ thresholds for the observed concentrations.

\begin{tabular}{|c|c|c|c|c|c|c|}
\hline Site & Latitude/longitude & Threshold (ppb) & $\operatorname{NMB}^{\mathrm{a}}(\%)$ & $\operatorname{NME}^{\mathrm{a}}(\%)$ & $\mathrm{RMSE}^{\mathrm{a}}$ (ppb) & $R^{\mathrm{a}}$ \\
\hline Mace Head & $53.33 /-9.90$ & none & -4.4 & 13.1 & 6.0 & 0.68 \\
\hline Ireland & & 40. & -15.2 & 15.7 & 8.2 & 0.25 \\
\hline Tsukuba & $36.05 / 140.13$ & none & 20.9 & 42.1 & 15.3 & 0.73 \\
\hline Japan & & 40. & -13.8 & 20.0 & 14.7 & 0.60 \\
\hline Ryori & $39.03 / 141.82$ & none & 4.5 & 23.5 & 12.2 & 0.38 \\
\hline Japan & & 40. & -12.3 & 15.5 & 10.3 & 0.26 \\
\hline Minamitorishima & $24.28 / 153.98$ & none & 20.8 & 37.7 & 10.0 & 0.66 \\
\hline Japan & & 40. & -28.1 & 28.1 & 16.5 & 0.28 \\
\hline Yonagunijima & $24.47 / 123.02$ & none & 7.5 & 29.5 & 11.3 & 0.84 \\
\hline Japan & & 40. & -15.4 & 16.7 & 11.2 & 0.52 \\
\hline Algoma & $47.03 /-84.38$ & none & 46.1 & 57.6 & 19.5 & 0.20 \\
\hline Canada & & 40. & -14.7 & 17.3 & 9.0 & 0.07 \\
\hline Bratt's Lake & $50.20 /-104.71$ & none & 33.5 & 44.8 & 15.4 & 0.39 \\
\hline Canada & & 40. & -5.0 & 20.5 & 11.8 & 0.16 \\
\hline Chapais & $49.82 /-74.98$ & none & 26.4 & 36.9 & 13.7 & 0.48 \\
\hline Canada & & 40. & -8.5 & 13.3 & 7.3 & 0.46 \\
\hline Experimental Lakes Area & $49.67 /-93.72$ & none & 33.2 & 40.6 & 15.5 & 0.27 \\
\hline Canada & & 40. & -4.4 & 14.9 & 8.7 & 0.13 \\
\hline Kejimkujik & $44.43 /-65.20$ & none & 37.7 & 42.8 & 16.1 & 0.35 \\
\hline Canada & & 40. & 1.0 & 13.8 & 8.4 & 0.39 \\
\hline
\end{tabular}

a NMB is normalized mean bias; NME is normalized mean error; RMSE is root mean square error; $R$ is correlation coefficient

August 2010, two sites likely to be influenced by transport of $\mathrm{O}_{3}$ from Asia. Figures $\mathrm{S} 1$ and $\mathrm{S} 2$ in the Supplement give comparisons for the other sites. In addition to the measurement data and results for the G-base simulation, results are also included for the G-bkgd simulation to indicate the impact of worldwide anthropogenic emissions on $\mathrm{O}_{3}$ above the surface.

At Trinidad Head, there is relatively good agreement between the G-base $\mathrm{O}_{3}$ and the ozonesonde measurements at altitudes up to the mid-troposphere $(\sim 7 \mathrm{~km})$ that are most influential to ground-level $\mathrm{O}_{3}$ in the Intermountain West and eastern US (Nopmongcol et al., 2017). However, the G-base $\mathrm{O}_{3}$ is greater than the measurements in the marine boundary layer $(<1 \mathrm{~km})$ in August and less than the measurements at upper altitudes in April. At Hilo, the G-base $\mathrm{O}_{3}$ is very close to the measurements in April and to the surface measurements in August but overestimates the measurements above the surface in August. At sites interior to the US (Boulder, Huntsville, Narragansett), the modeled $\mathrm{O}_{3}$ agrees well with the measurements in April below $7 \mathrm{~km}$ but is consistently greater than the measurements by $\geq 20 \mathrm{ppb}$ in August. The G-base $\mathrm{O}_{3}$ at Summit agrees reasonably well with the measurements below $7 \mathrm{~km}$ in August but underpredicts the measurements in April. Agreement at the South Pole is very good at all altitudes.

Near the top boundary of the CAMx domain, GEOS-Chem consistently overpredicts $\mathrm{O}_{3}$ for midlatitude sites (Boulder, Hilo, Huntsville, Narragansett, Trinidad Head) (Fig. S3).
From 15 to $25 \mathrm{~km}$, the predictions for the G-base case are up to $1200 \mathrm{ppb}$ greater than measurements. To the extent that this stratospheric air is mixed downward, it would contribute to any overpredictions by GEOS-Chem and CAMx in the troposphere.

We also compared GEOS-Chem predictions to observations at CASTNet sites, which are rural locations (US EPA, 2016a). Following Fiore et al. (2014), Fig. 4 presents a comparison of monthly average MDA8 $\mathrm{O}_{3}$ from the G-base and G-bkgd simulations to the observations at high-altitude (> $1.5 \mathrm{~km}$ ) Intermountain West sites (except CA) and at lowaltitude $(<1.5 \mathrm{~km})$ sites. (Sites are shown in Fig. S4.) In March and April, the G-base $\mathrm{O}_{3}$ agrees well with observations at low-altitude sites and somewhat underestimates observations at the high-altitude sites but, in summer, significantly overestimates the observations at all altitudes. Also, the observations show a small decreasing trend from spring to summer whereas the G-base results show a clear increasing trend. The G-bkgd results parallel those of G-base, approaching the observed mean $\mathrm{MDA} 8 \mathrm{O}_{3}$ for the high-altitude sites in August, suggesting that the summer $\mathrm{O}_{3}$ overestimation of the G-base simulation is largely caused by overestimating the non-anthropogenic contribution. Other studies indicate that overestimated lightning $\mathrm{NO}_{x}$ emissions in the southern US (below $35^{\circ} \mathrm{N}$ ) may explain the positive GEOSChem bias in summer at the Intermountain West sites (Zhang et al., 2014; Travis et al., 2016). The positive bias in summer at the low-altitude sites may be due to overestimated light- 

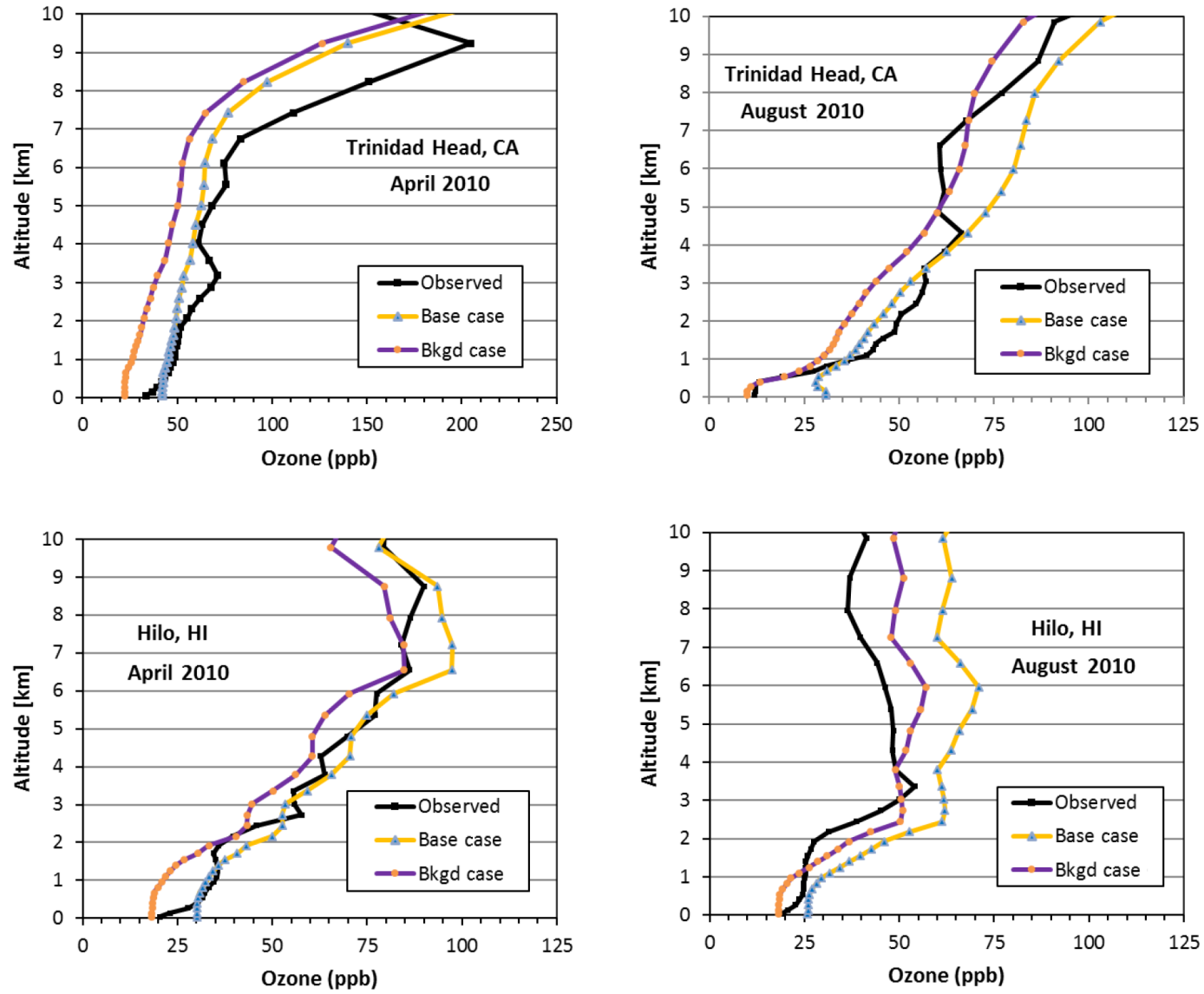

Figure 3. Comparison of GEOS-Chem vertical $\mathrm{O}_{3}$ profiles for the base and background cases in April and August to ozonesonde measurements at a site on the west of the continental US (Trinidad Head) and west of the CAMx domain (Hilo). Monthly averages are shown.

ning $\mathrm{NO}_{x}$ emissions and/or excessive vertical mixing (Travis et al., 2016). GEOS-Chem may also overestimate the contribution of US anthropogenic emissions to summer $\mathrm{O}_{3}$, e.g., because of coarse horizontal grid resolution or because $\mathrm{NO}_{x}$ emissions are overestimated in EPA's 2011 National Emissions Inventory (Travis et al., 2016), but the August ozone soundings at continental US sites (Fig. S1) suggest otherwise because the $\mathrm{O}_{3}$ overprediction is larger in the midtroposphere than near ground level. Lack of halogen chemistry may also contribute to the $\mathrm{O}_{3}$ overpredictions (Schmidt et al., 2016; Sherwen et al., 2016). Seasonal averages and the fourth-highest $\mathrm{MDA} 8 \mathrm{O}_{3}$ concentrations in the North American domain for the G-base and G-bkgd cases are shown in Fig. S5.

The GEOS-Chem evaluation at surface and ozonesonde sites outside the US shows both over- and underprediction compared to measurements (Table 2, Figs. 3, S2), which introduces uncertainty in the BCs for CAMx. The GEOSChem positive bias in summer at sites within the US (Figs. 4, S1) should not directly influence our modeling with CAMx for the North American domain.
It is difficult to compare our performance with the GEOSChem model to that in recent studies due to differences in the version and configuration of the model, the emissions used, the year simulated, and the observational data compared to the model results. Given these limitations, our performance is similar to what some others have obtained (Zhang et al., 2008; Emery et al., 2012; Nopmongcol, 2016). However, Zhang et al. (2014), who reduced lightning $\mathrm{NO}_{x}$ emissions, Travis et al. (2016), who reduced lightning and anthropogenic $\mathrm{NO}_{x}$ emissions, and Yan et al. (2016), who used three two-way nested models within GEOS-Chem, obtained better performance than we did. Fiore et al. (2014) also found better performance for GEOS-Chem in their analysis corresponding to Fig. 4.

An alternative global model is the Geophysical Fluid Dynamics Laboratory's Atmospheric Model 3 (AM3) (Donner et al., 2011). GEOS-Chem and AM3 have important differences in biogenic isoprene emissions and chemistry, lightning $\mathrm{NO}_{x}$ and wildfire emissions, and stratosphere-totroposphere transport (Fiore et al., 2014). Fiore et al. (2014) found that $\mathrm{AM} 3$ gives greater background $\mathrm{O}_{3}$ at high-altitude western surface sites in spring than GEOS-Chem. This may 

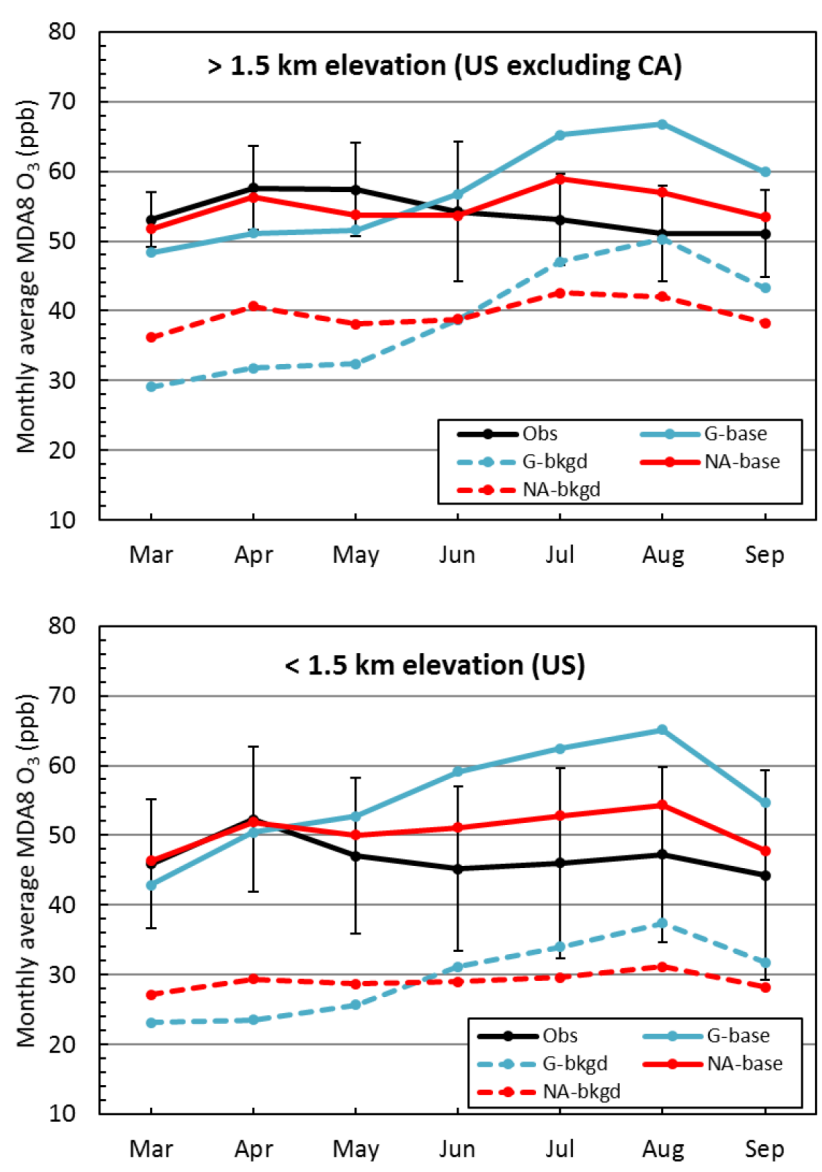

Figure 4. Observed and modeled monthly average MDA8 $\mathrm{O}_{3}$ at high- and low-altitude CASTNet sites in 2010. G-base and Gbkgd are the GEOS-Chem global model base and background cases whereas NA cases are the CAMx North American model. Error bars for observations indicate 1 standard deviation. Site locations are shown in Fig. S4.

be due to more stratosphere-to-troposphere transport in AM3 (Lin et al., 2012) and/or more efficient mixing of free tropospheric air into the planetary boundary layer. Emery et al. (2013) found that CAMx simulations using BCs from GEOS-Chem had better performance for maximum daily average $8 \mathrm{~h}$ (MDA8) $\mathrm{O}_{3}$ at EPA's Clean Air Status and Trends Network (CASTNet) sites (US EPA, 2016a) in April-May than simulations using BCs from AM3; BCs from GEOSChem and AM3 gave similar CAMx performance for JuneSeptember. Considering this work, we chose GEOS-Chem for the present study. However, AM3 may simulate the dayto-day variation in the stratospheric contribution to spring $\mathrm{O}_{3}$ in the western US better than GEOS-Chem (Lin et al., 2012; Fiore et al., 2014).

\subsection{Model performance for CAMx}

Figure 4 also contains results for the CAMx NA-base and NA-bkgd simulations at CASTNet sites. The NA-base re- sults are closer to the mean of the observations at both the high- and low-altitude sites than are the G-base results, and the NA-base results are always within 1 standard deviation of the mean. However, the NA-base results show essentially no trend from spring to summer whereas the measurements show a downward trend. The NA-bkgd results parallel the NA-base results $\sim 20 \mathrm{ppb}$ lower at the low-altitude sites and $\sim 15 \mathrm{ppb}$ lower at the high-altitude sites.

In addition to comparing CAMx predictions to observations at CASTNet sites, we evaluated performance for the sites reporting to EPA's Air Quality System (AQS), which are urban and suburban locations (US EPA, 2016b). Figure 5 presents a comparison of predicted $\mathrm{MDA} 8 \mathrm{O}_{3}$ concentrations from the NA-base case with observations at AQS and CASTNet sites, using a zero threshold for the observations. The normalized mean bias (NMB) is 4.5-5.1\% and the normalized mean error (NME) is 17.1-18.1\%, which suggest good performance. However, there is overprediction at the lower concentrations and underprediction at the higher concentrations similar to, but more pronounced than, that in other work (Emery et al., 2012; Nopmongcol et al., 2016, 2017).

To investigate further, we compared our BCs from GEOSChem to those provided by the European Centre for MediumRange Weather Forecasts (ECMWF) for AQMEII Phase 3 (Nopmongcol et al., 2017). Figure S6 compares simulations for summer with the two sets of BCs; deposition was included but chemistry and emissions were inactive. At the AQS and CASTNet sites, the GEOS-Chem BCs generally gave greater MDA8 $\mathrm{O}_{3}$ than the ECMWF BCs. This suggests that the GEOS-Chem BCs contribute to the overprediction in Fig. 5 at the lower concentrations. Plots of the simulated MDA8 $\mathrm{O}_{3}$ from the NA-bkgd case vs. the observations (not shown) display overprediction for observations $<20 \mathrm{ppb}$, so overprediction at low concentrations apparently exists in the background case also. The reasons for the underprediction at observed concentrations $>70 \mathrm{ppb}$ in Fig. 5 are not clear. Some of the underprediction could be due to the absence of the Canadian/Mexican wildfire emissions. Deriving CAMx BCs from the ECMWF model rather than GEOSChem would have improved performance of our NA-base case but was not viable because there was no matching simulation with zero anthropogenic emissions for our NA-bkgd case.

We also determined the NMB and NME for the NA-base simulation, focusing on the larger concentrations by using a $40 \mathrm{ppb}$ threshold for the MDA8 $\mathrm{O}_{3}$ observations (Table S6). The NMB and NME ranged from -4.9 to $4.3 \%$ and 12.1 to $14.2 \%$, respectively, at the AQS and CASTNet sites in spring and summer, which are similar magnitude NMB and smaller NME than with the zero threshold. This performance is comparable to that obtained by Nopmongcol et al. (2017) for AQMEII Phase 3 (Table S6) using a similar CAMx configuration and inputs (except for BCs, dry deposition scheme, lightning $\mathrm{NO}_{x}$ and biogenic emissions), indicating that factors shared by these two simulations (e.g., anthropogenic 

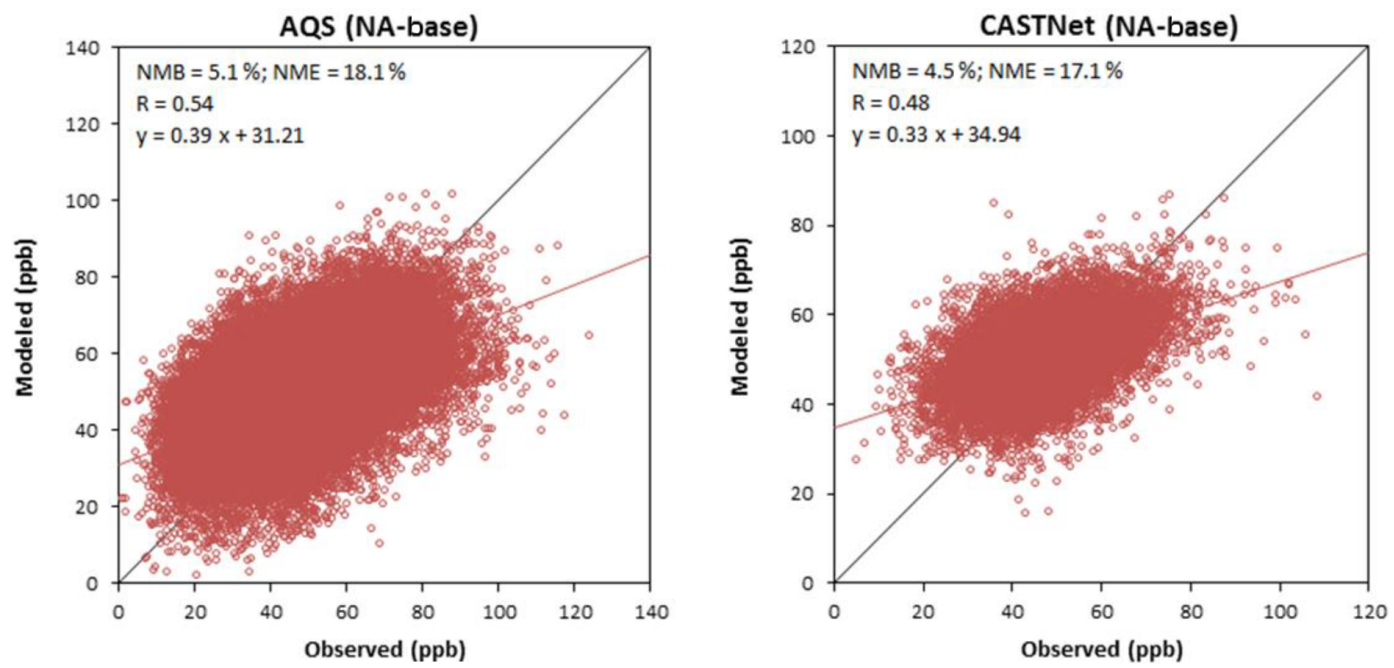

Figure 5. Scatter plots of modeled MDA8 $\mathrm{O}_{3}$ concentrations from the CAMx base case vs. observations at AQS and CASTNet sites for March-September 2010. The black and red lines are one-to-one and linear regression lines, respectively. Normalized mean bias (NMB) and normalized mean error (NME) were calculated with no threshold.

emissions, chemistry scheme, meteorology) are most influential on the larger $\mathrm{O}_{3}$ concentrations.

\subsection{Boundary concentrations from GEOS-Chem}

The monthly average $\mathrm{O}_{3}$ concentrations on the lateral boundaries of the CAMx domain are shown in Fig. 6 for the surface layer and layer 23, which is centered near $10 \mathrm{~km}$ altitude. Mostly, layer 23 represents the upper troposphere except near the northern boundary in late spring, where the tropopause is lower (Seidel and Randel, 2006) and thus layer 23 represents the lower stratosphere. In the surface layer for the western, eastern, and southern boundaries, the $\mathrm{O}_{3}$ concentration is $30-45 \mathrm{ppb}$ for the base case, and there is a minimum in June or July. On the north boundary, the concentration is generally lower by up to $9 \mathrm{ppb}$ than on the other boundaries. For layer 23 , there is a decreasing trend from spring to summer on the northern, western, and eastern boundaries and no clear trend on the south boundary; the $\mathrm{O}_{3}$ concentration is greatest on the north, similar on the west and east, and least on the southern boundary. In April, layer 23 of the western boundary shows a springtime maximum in upper-tropospheric $\mathrm{O}_{3}$, which has been associated with events of high ground level $\mathrm{O}_{3}$ in the Intermountain West (Zhang et al., 2014) when air descends from high altitude to ground level with little dilution. In the base case, the concentration for layer 23 is 20 $134 \mathrm{ppb}$ greater than for the surface layer, reflecting destruction at the surface. These trends in the base-case $\mathrm{BCs}$ are consistent with our understanding of tropospheric $\mathrm{O}_{3}$ in the Northern Hemisphere.

The boundary concentrations for the NA-bkgd case closely parallel those for the NA-base case on all lateral boundaries in layer 23 and on the west in the surface layer. The anthro- pogenic increment to the lateral boundary concentrations is $7-22 \mathrm{ppb}$ in the surface layer and $8-20 \mathrm{ppb}$ in layer 23 . This increment is a large fraction (generally $30-60 \%$ ) of the basecase boundary concentrations for the surface layer but a moderate fraction (10-21\%) for layer 23. The April and August average $\mathrm{O}_{3}$ concentrations on the top boundary of the CAMx domain, at $14-17 \mathrm{~km}$, are shown in Fig. S7 for the base case along with the anthropogenic increment. The increment for the top boundary is of similar magnitude to that on the lateral boundaries for layer 23 and the surface layer. However, the anthropogenic increment on the top boundary is only a small fraction (typically $1-5 \%$ ) of the top boundary concentration for the base case. Thus, GEOS-Chem predicts a positive but only small influence of anthropogenic emissions on $\mathrm{O}_{3}$ in the lower stratosphere, and the $\mathrm{O}_{3}$ difference on the top boundary between the NA-base and NA-bkgd simulations should give only a small contribution to the source apportionment (confirmed below).

\subsection{Base-case and background ozone}

The spring (March-May) and summer (June-August) seasonal averages of MDA8 $\mathrm{O}_{3}$ from the NA-base and NA-bkgd simulations are given in Fig. 7. Also shown is the average of the 10 largest MDA8 $\mathrm{O}_{3}$ concentrations in the base case (T10base) over March-September and the average over the same days in the background simulation. (The T10base dates can differ by grid cell.) Our goal with the T10base metric is to include a reasonable variety of days with large MDA8 $\mathrm{O}_{3}$, but this metric is not directly related to a regulatory standard. For the base case in spring, the larger $\mathrm{O}_{3}$ concentrations are in an arc from British Columbia through the Rocky Mountains into the Sierra Madre mountains of Mexico, across the 

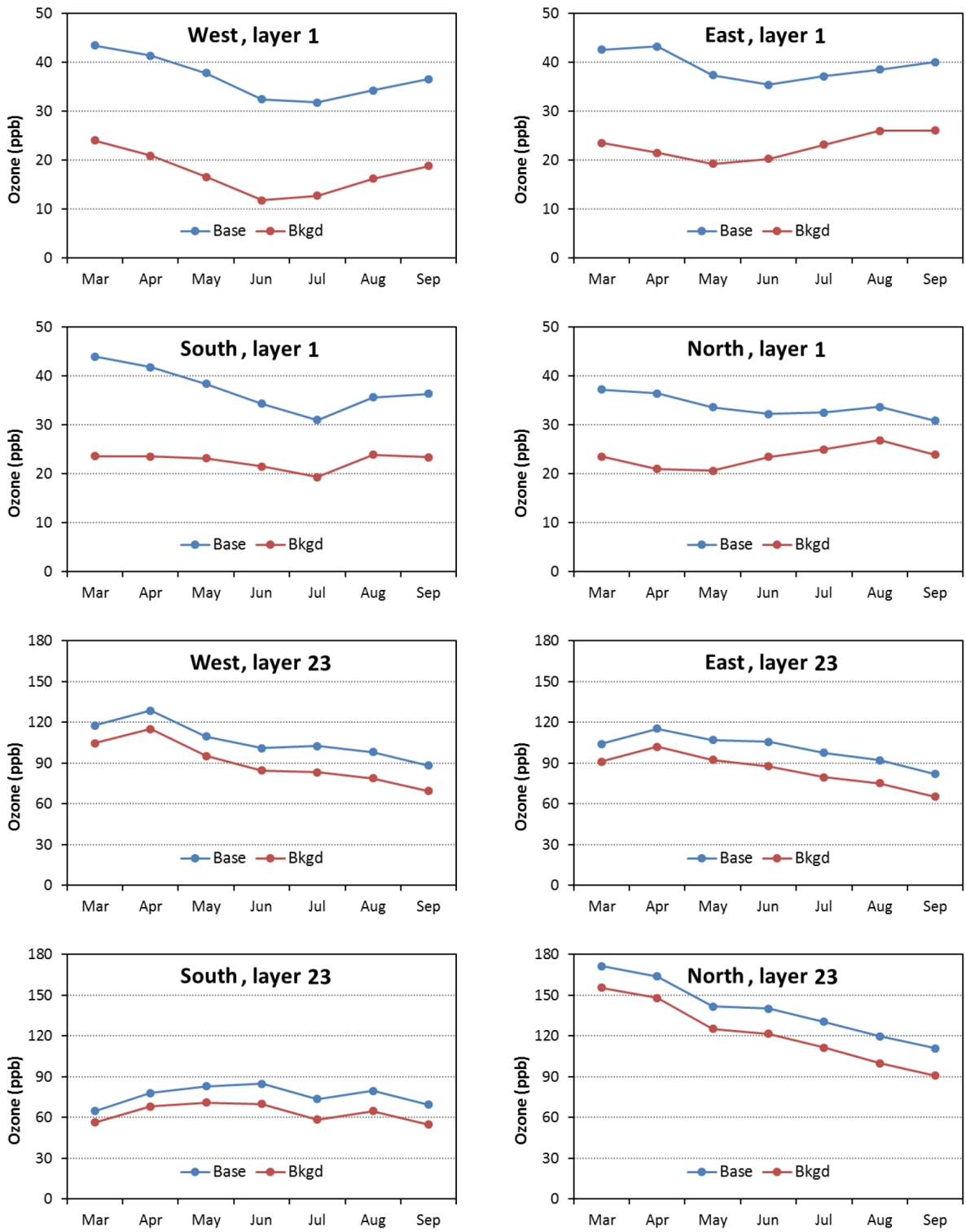

Figure 6. Monthly average lateral boundary $\mathrm{O}_{3}$ concentrations for the CAMx surface layer and the 23rd layer, as provided by the GEOSChem simulations.

Gulf of Mexico, and along the US east coast. The background $\mathrm{O}_{3}$ in spring has a similar spatial pattern with the largest concentrations of 40-50 ppb in Colorado, New Mexico, Arizona, and Mexico. However, in the base case, the $\mathrm{O}_{3}$ levels in the western and eastern US are similar, but in the background case the levels are distinctly lower in the eastern than western US.

The summer average for the base case shows MDA8 $\mathrm{O}_{3}$ greater than $50 \mathrm{ppb}$ across most of the US. The largest concentrations are near or downwind of urban areas and in Colorado with the maximum of $69 \mathrm{ppb}$ near Washington, DC. The spatial pattern of the background concentration in summer is like that in spring except that concentrations are smaller in Mexico and larger in Canada than in spring. The largest background concentrations are in Colorado and California, and the maximum is $47 \mathrm{ppb}$ in the Sierra Nevada mountains.

The T10base average for the base case shows an even more pronounced impact of urban areas with larger concentrations also in Colorado, New Mexico, and Mexico. The maximum concentration is $96 \mathrm{ppb}$, again near Washington, DC. The T10base average for the background case assigns the largest concentrations to central Canada, the western US, and Mexico. The maximum background of $64 \mathrm{ppb}$ is in the Sierra Madre Occidental mountains of Mexico, but there are also locations in Colorado, New Mexico, Arizona, and California that exceed $60 \mathrm{ppb}$. 
(a) Spring

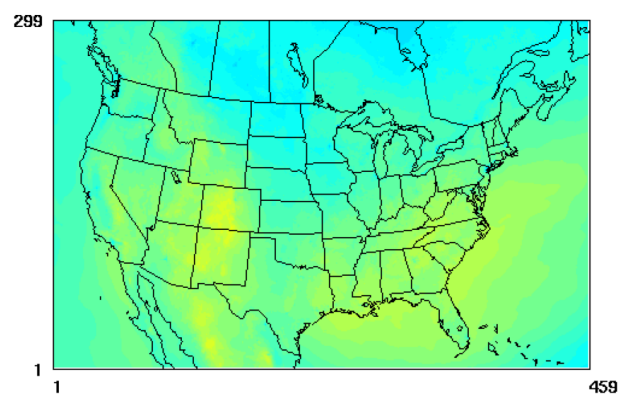

Min= 0.0 at (1.1). $\max =60.2$ at $(154.120)$

(b) Summer

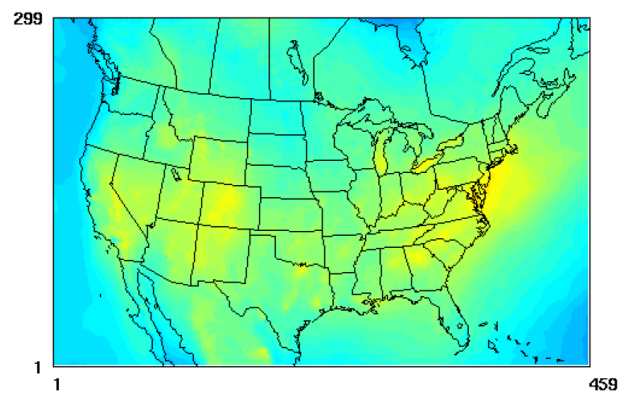

Min= 0.0 at $(1.1), \max =69.1$ at $(361.149)$

(c) T10Base

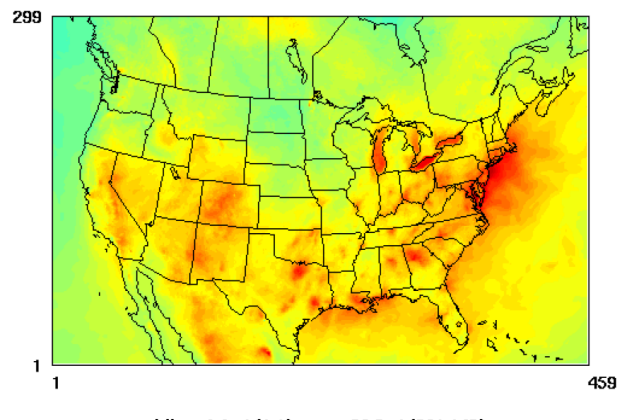

(d) Spring

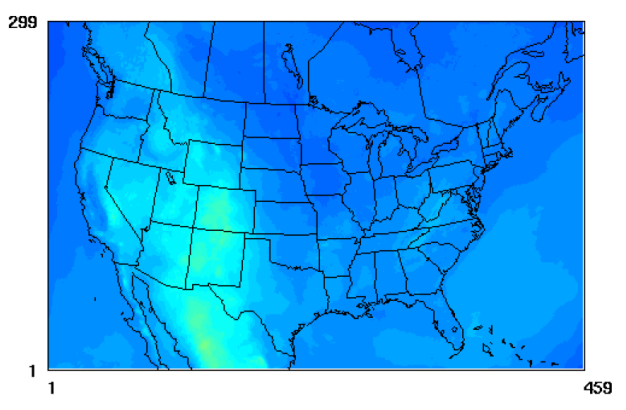

$\operatorname{Min}=0.0$ at (1.1), $\max =49.2$ at $(136.20)$

(e) Summer

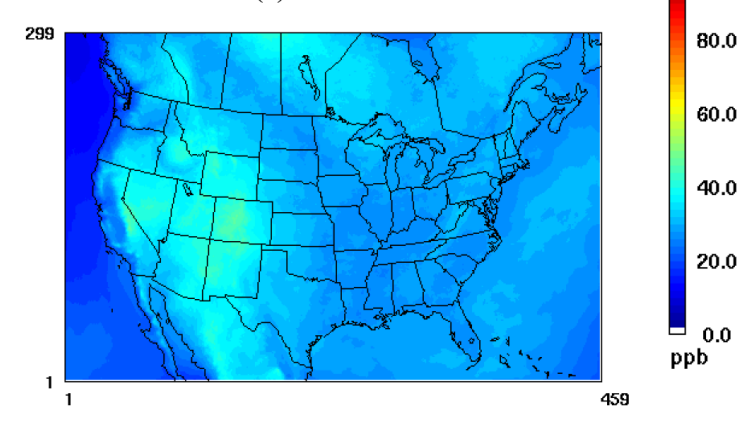

Min= 0.0 at $(1.1), \max =46.6$ at $(56.132)$

(f) T10Base

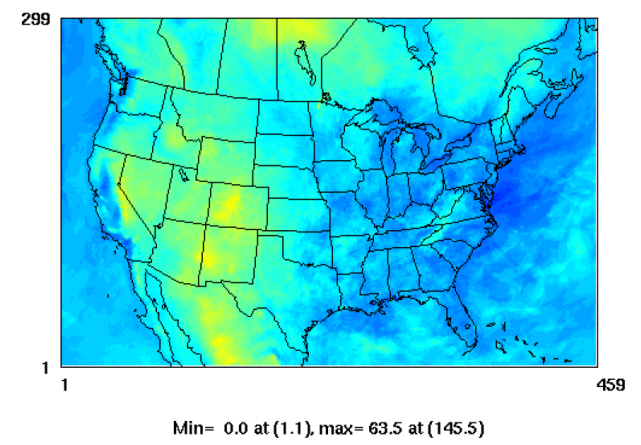

Figure 7. $\mathrm{MDA} 8 \mathrm{O}_{3}$ concentrations from the CAMx base (a-c) and background (d-f) simulations averaged over spring (March-May), summer (June-August), and the 10 days in the base case with the largest concentrations during March-September 2010 (T10base).

Table 3 gives the T10base concentrations for the base and background cases at 10 urban and 2 CASTNet sites. In choosing sites to represent urban areas, we selected the site with highest design value in each urban area. (Site IDs are in Table S7.) Also in the table are the base and background concentrations averaged over the 10 days with the largest background concentrations (T10bkgd). For the base case, the T10base averages exceed $70 \mathrm{ppb}$ at all the sites except Sacramento, Salt Lake, Big Bend, and Perkinstown, and the T10bkgd averages exceed $60 \mathrm{ppb}$ at half the sites. The background concentrations are largest at the higherelevation $(>1 \mathrm{~km})$ sites: Denver, Salt Lake, and Big Bend. The T10bkgd average for the background case ranges from
35 to $54 \mathrm{ppb}$ at the 12 sites, and the T10base average background ranges from 24 to $50 \mathrm{ppb}$.

The ratio of the background MDA8 $\mathrm{O}_{3}$ concentration to the base-case concentration is shown in Fig. 8 for the spring, summer, and T10base averages (ratio $=$ background average/base average). For all three averages, the ratio is larger at most locations in the western US than the eastern US, and the difference between the western and eastern US becomes greater from the spring to summer to T10base averages. The background $\mathrm{O}_{3}$ generally becomes both a larger fraction of the base-case $\mathrm{O}_{3}$ in the western US and a smaller fraction in the eastern US as the base-case $\mathrm{O}_{3}$ increases across the three averages. Table S8 gives the ratio for the same 12 sites as in Table 3 for the spring, summer, T10base, and T10bkgd 
Table 3. Contributions of anthropogenic sources to the anthropogenic increment of $\mathrm{MDA} 8 \mathrm{O}_{3}$ at AQS and CASTNet sites ${ }^{\mathrm{a}}$.

\begin{tabular}{|c|c|c|c|c|c|c|c|c|c|c|}
\hline \multirow[b]{2}{*}{ Site ${ }^{\mathrm{d}}$} & \multicolumn{5}{|c|}{ T10base $(\mathrm{ppb})^{\mathrm{b}}$} & \multicolumn{5}{|c|}{ T10bkgd $(\mathrm{ppb})^{\mathrm{c}}$} \\
\hline & Base & Bkgd & $\begin{array}{r}\text { US } \\
\text { anthro }\end{array}$ & $\begin{array}{r}\text { Can/Mex } \\
\text { anthro }\end{array}$ & $\begin{array}{r}\text { Anthro } \\
\text { lateral BCs }\end{array}$ & Base & Bkgd & $\begin{array}{r}\text { US } \\
\text { anthro }\end{array}$ & $\begin{array}{r}\text { Can/Mex } \\
\text { anthro }\end{array}$ & $\begin{array}{r}\text { Anthro } \\
\text { lateral } \mathrm{BCs}\end{array}$ \\
\hline Atlanta, GA & 83.3 & 28.4 & 48.3 & 0.4 & 3.6 & 60.6 & 41.2 & 11.3 & 0.4 & 6.3 \\
\hline Boston, MA & 75.5 & 24.4 & 45.5 & 1.8 & 2.8 & 55.6 & 35.1 & 13.2 & 1.9 & 5.2 \\
\hline Cleveland, $\mathrm{OH}$ & 73.1 & 26.1 & 39.8 & 3.2 & 3.4 & 58.1 & 40.8 & 9.7 & 1.9 & 5.7 \\
\hline Dallas, TX & 82.5 & 31.3 & 45.3 & 0.6 & 3.5 & 57.1 & 42.6 & 5.2 & 0.4 & 7.8 \\
\hline Denver, CO & 72.2 & 49.9 & 11.9 & 0.2 & 9.4 & 68.2 & 54.1 & 3.4 & 0.5 & 9.6 \\
\hline Pittsburgh, PA & 76.2 & 25.5 & 46.0 & 0.8 & 3.3 & 62.7 & 42.9 & 12.1 & 0.9 & 6.8 \\
\hline Sacramento, CA & 69.8 & 24.9 & 39.3 & 0.3 & 4.6 & 60.3 & 37.3 & 12.9 & 0.4 & 9.5 \\
\hline Salt Lake, UT & 66.2 & 43.7 & 13.2 & 0.3 & 8.4 & 62.4 & 46.2 & 6.6 & 0.3 & 8.9 \\
\hline St. Louis, MO & 76.3 & 26.1 & 45.8 & 0.5 & 3.0 & 55.6 & 40.1 & 6.9 & 0.7 & 8.0 \\
\hline Washington, DC & 83.8 & 25.5 & 53.4 & 1.2 & 2.8 & 59.7 & 38.6 & 13.2 & 0.7 & 7.0 \\
\hline Big Bend, TX & 62.7 & 46.5 & 6.0 & 2.0 & 8.3 & 60.7 & 48.6 & 2.7 & 1.2 & 8.2 \\
\hline Perkinstown, WI & 57.6 & 38.2 & 13.0 & 0.6 & 5.8 & 54.7 & 43.0 & 5.2 & 1.1 & 5.5 \\
\hline
\end{tabular}

a Anthropogenic component of the top BCs contributes $\leq 0.1 \mathrm{ppb}$.

${ }^{b}$ Average of the 10 days with largest MDA $8 \mathrm{O}_{3}$ in the base case. Days for the background case are the same as the base case.

c Average of the 10 days with largest MDA8 $\mathrm{O}_{3}$ in the background case. Days for the base case are the same as the background case.

d IDs are in Table S7.

(a) Spring

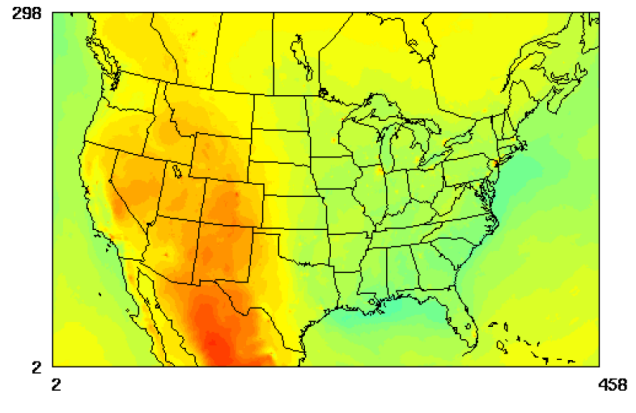

$\operatorname{Min}=47.0$ at (283.52), $\max =89.1$ at $(245.208)$ (b) Summer

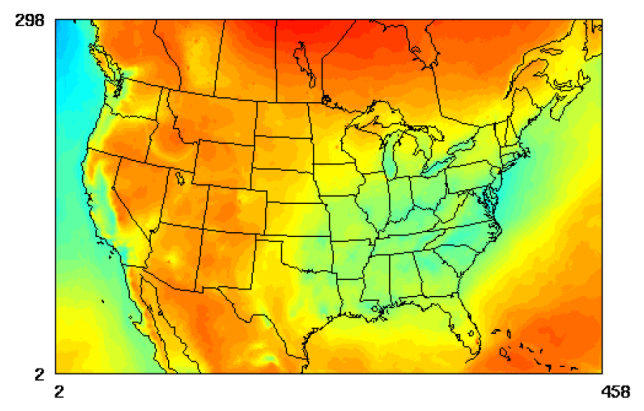

$\operatorname{Min}=28.3$ at (2.298), $\max =120.8$ at $(245.208)$

(c) T10base

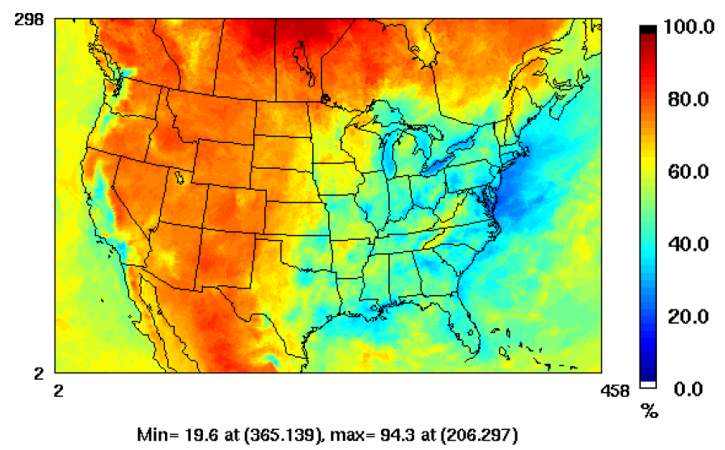

Figure 8. Ratio of the background $\mathrm{MDA} 8 \mathrm{O}_{3}$ to the base-case $\mathrm{MDA} 8 \mathrm{O}_{3}$ for (a) spring, (b) summer, and (c) T10base averages.

averages. For the largest $\mathrm{O}_{3}$ concentrations (T10base), Denver, Salt Lake, and Big Bend have the largest ratios (69, 66, and $74 \%$, respectively) and Boston, Pittsburgh, and Washington, DC, the smallest ratios $(32,33$, and $30 \%$, respec- tively). There are some exceptions to the general trend of larger ratios in the western than eastern US; e.g., the ratios for Sacramento and Perkinstown are 36 and $66 \%$, respectively. 
(a) Anthropogenic increment

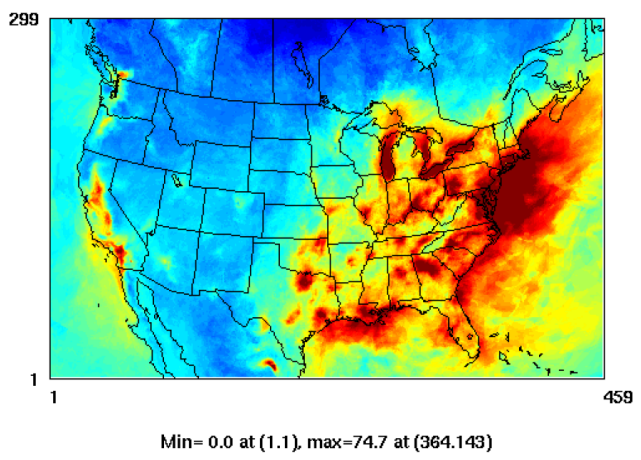

(c) Can/Mex anthro emissions

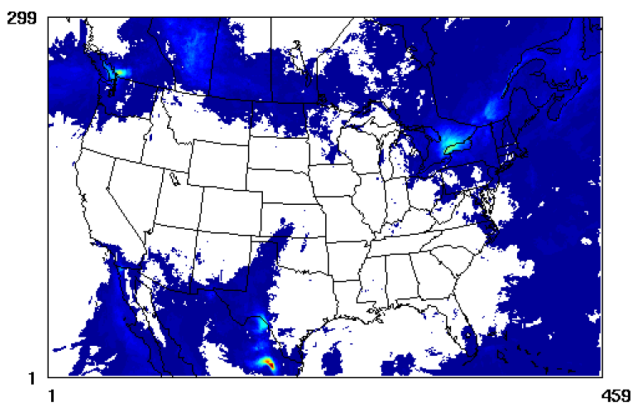

Min=-9.5 at (183.38), $\max =50.6$ at $(186.10)$ (b) US anthro emissions

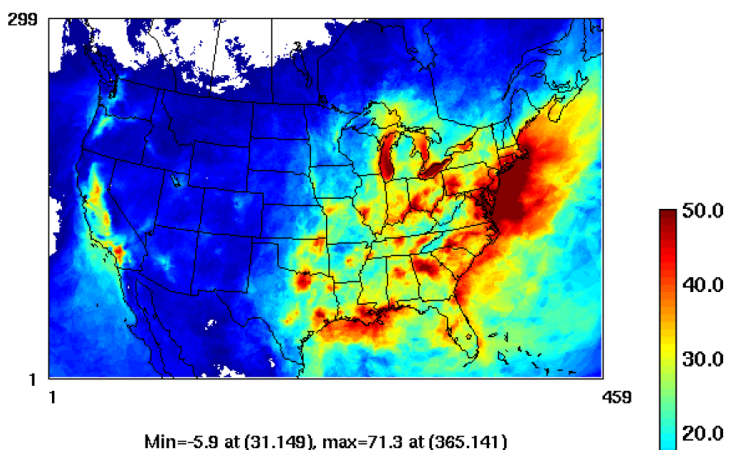

(d) Anthro lateral BCs

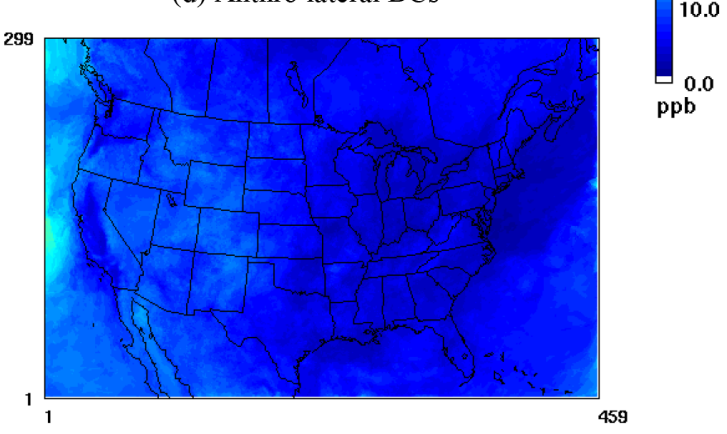

Min= 0.0 at (1.1), $\max =23.8$ at (2.144)

Figure 9. The anthropogenic increment (a) for the average of the top $10 \mathrm{MDA} 8 \mathrm{O}_{3}$ concentrations in the base case (T10base) and the contributions (b-d) to this increment. The contribution from the anthropogenic component of the top BCs is $\leq 0.5 \mathrm{ppb}$.

\subsection{Source apportionment of the anthropogenic increment}

The PIM quantifies source contributions by numerically integrating Eq. (1), and we evaluated the accuracy of the numerical integration by comparing the sum of the contributions to the anthropogenic increment (right-hand side vs. lefthand side of Eq. (1), respectively). Including all surface grid squares in the CAMx domain, the sum of the contributions to MDA8 $\mathrm{O}_{3}$ correlated closely $\left(R^{2}=0.999\right.$, least squares slope $=0.99)$ with the anthropogenic increment in March and June (Fig. S8). At selected AQS and CASTNet sites, the maximum error and average error over the 7-month simulation are $<3.5$ and $<1.5 \mathrm{ppb}$, respectively (Fig. S9). Errors are smaller at the CASTNet sites than at the AQS sites, most likely because the concentrations are smaller at the CASTNet sites. This accuracy is very similar to that in our previous application of the PIM for a 3-D simulation. (Dunker et al., 2015).

The anthropogenic increment to MDA8 $\mathrm{O}_{3}$ in ppb, based on the T10base average, is shown in Fig. 9 along with the source contributions to the increment from the PIM. Analogous plots for the spring- and summer-average MDA8 $\mathrm{O}_{3}$ are in Figs. S10 and S11, respectively. The relative source contributions in percent are in Figs. 10, S12, and S13. These figures do not show the contribution from the anthropogenic component of the top BCs because this contribution to surface concentrations is always very small, $\leq 0.5 \mathrm{ppb}$ or $\leq 3 \%$ of the increment. The small magnitude is consistent with the small fraction of the top BCs arising from anthropogenic emissions, as predicted by GEOS-Chem (Fig. S7). The small contribution of anthropogenic top BCs does not preclude a larger contribution from natural stratospheric $\mathrm{O}_{3}$. We omit further analysis of the anthropogenic top BCs contribution.

The anthropogenic increment is larger to the east of midTexas and along the west coast than in the states in between and generally larger in summer than spring. The maximum increment is $30 \mathrm{ppb}$ in spring along the Louisiana coast, $42 \mathrm{ppb}$ in summer near Washington, DC, and $75 \mathrm{ppb}$ for the T10base average, also near Washington, DC. The US anthropogenic emissions are the largest contributor in ppb and percent to the anthropogenic increments in the eastern US and California. This is apparent in Figs. 9 and 10 and also in the source contributions for the T10base average in Table 3. For the cities in Table 3 in the eastern US and California (all but Denver and Salt Lake), the US anthropogenic emissions contribute $39-53 \mathrm{ppb}(86-93 \%)$ of the T10base increments.

The anthropogenic lateral BCs are the second-most important contributor in ppb to the anthropogenic increment at most locations in the domain (Fig. 9). The contributions 
(a) US anthro emissions

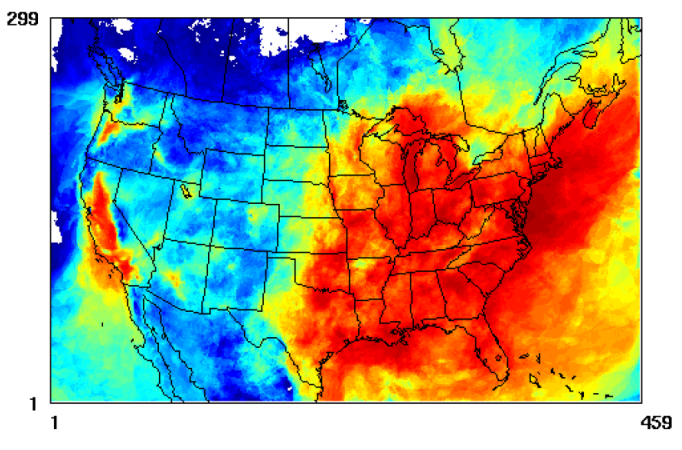

Min $=0.0$ at $(1.1), \max =97.1$ at $(365.139)$ (b) Can/Mex anthro emissions

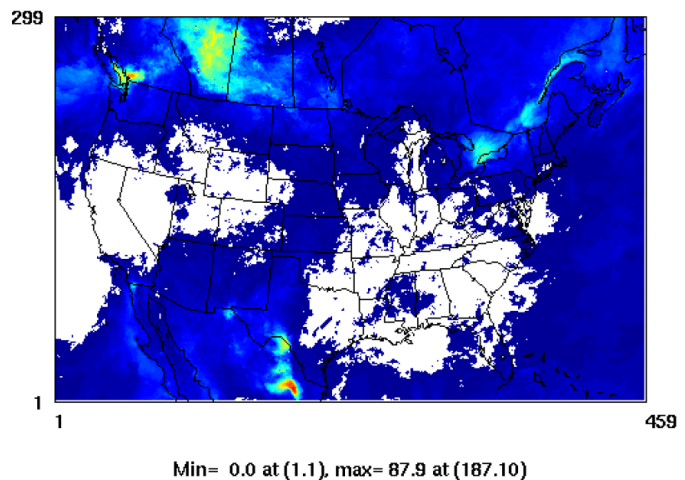

(c) Anthro lateral BCs

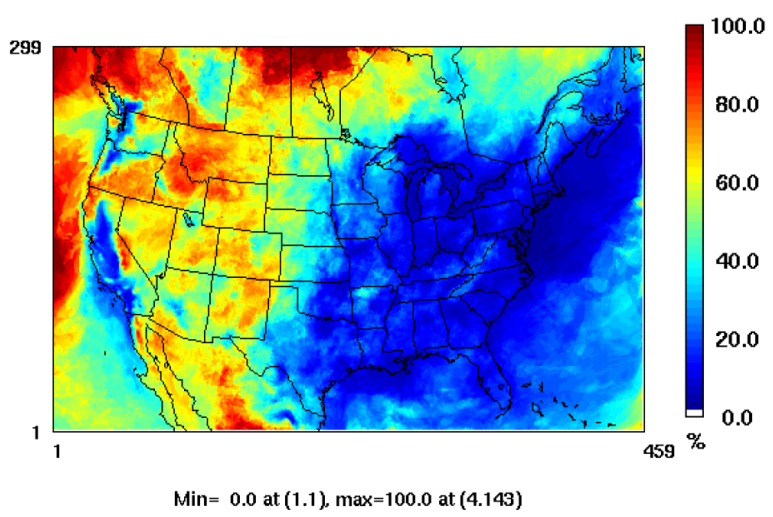

Figure 10. Relative contributions in percent to the anthropogenic increment of the T10base $\mathrm{MDA}_{8} \mathrm{O}_{3}$ concentrations. The contribution from the anthropogenic component of the top $\mathrm{BCs}$ is $\leq 3 \%$.

are largest for higher-elevation US sites in the Intermountain West and along the western boundary of the CAMx domain, consistent with transport of pollutants from Asia. The lateral BCs contribute $8-9$ ppb (39-51\%) of the T10base anthropogenic increments at Denver, Salt Lake, and Big Bend (Table 3). At Perkinstown (northern WI), the lateral BCs contribute $6 \mathrm{ppb}(30 \%)$ of the increment. The contribution of the lateral BCs decreases from the western boundary across the US and increases from the US east coast toward the east boundary. The increase toward the east boundary is greatest in spring in the northeast and may be due to transport of Canadian emitted species and $\mathrm{O}_{3}$ from inside to outside the CAMx domain and recirculation back through the east boundary via the BCs from GEOS-Chem. On a relative basis, the lateral BCs are important where the US emissions are not very important and vice versa (Figs. 10, S12, S13).

The Canadian/Mexican anthropogenic emissions are third in importance, affecting the northern, east-coast, and southwest US and some interior states. In summer, these emissions also contribute $\sim 2 \mathrm{ppb}$ to the anthropogenic increment along the west coast, south to San Francisco (Fig. S11). The spatial pattern is consistent with prevailing summer surface winds, which circulate anticyclonically around the east- ern Pacific subtropical high-pressure area. At sites in Table 3 close to Canada and Mexico, Cleveland, and Big Bend, the Canadian/Mexican emissions contribute $3 \mathrm{ppb}(7 \%)$ and $2 \mathrm{ppb}(12 \%)$, respectively, to the T10base anthropogenic increment.

Table 3 also contains the source contributions obtained with the T10bkgd average. The anthropogenic increment from the T10bkgd average is $6-37$ ppb lower at the urban sites and 4-8 ppb lower at the CASTNet sites compared to the increment from the T10base average. This reduction is due to a reduced contribution from the US emissions. The contribution of the Canadian/Mexican emissions remains about the same at all the sites with the T10bkgd average, and the contribution of the lateral BCs increases by $2-5 \mathrm{ppb}$ at the lower-elevation urban sites. The net effect is that the relative importance of the lateral BCs is significantly increased for the days with the largest background concentrations. For five sites, the contribution exceeds $50 \%$ of the anthropogenic increment and at Denver and Big Bend, the lateral BCs account for 71 and $67 \%$ of the increment, respectively.

Figure 11 has time series of the base-case and background concentrations and the source contributions for five of the sites in Table 3. Time-series plots for other AQS and CAST- 

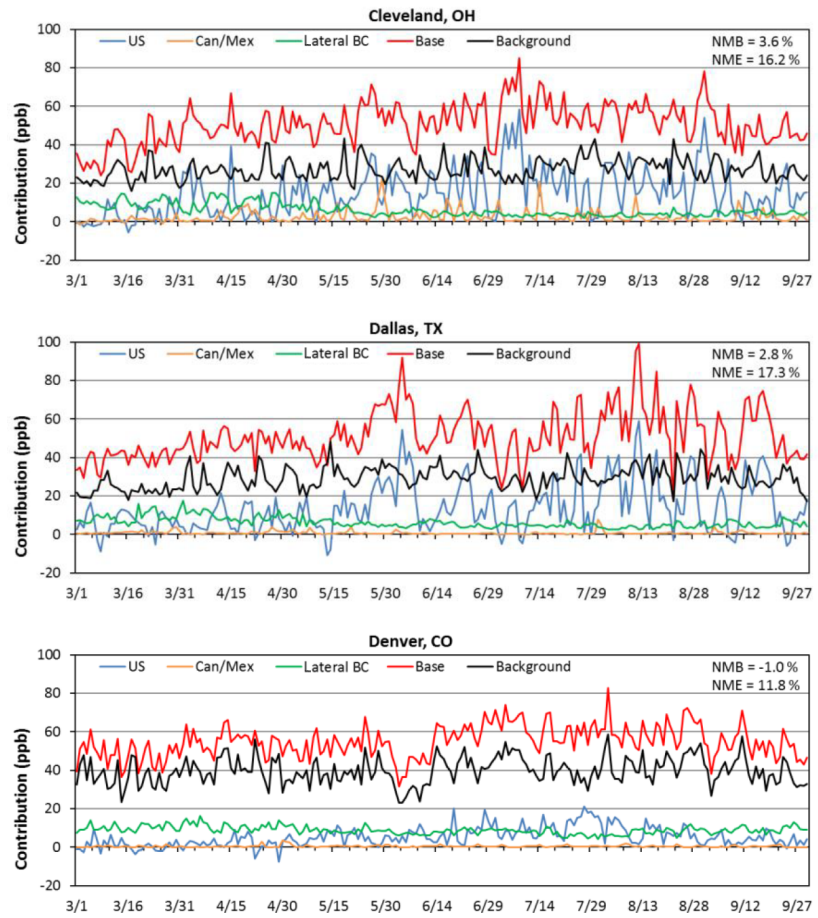

Big Bend NP, TX
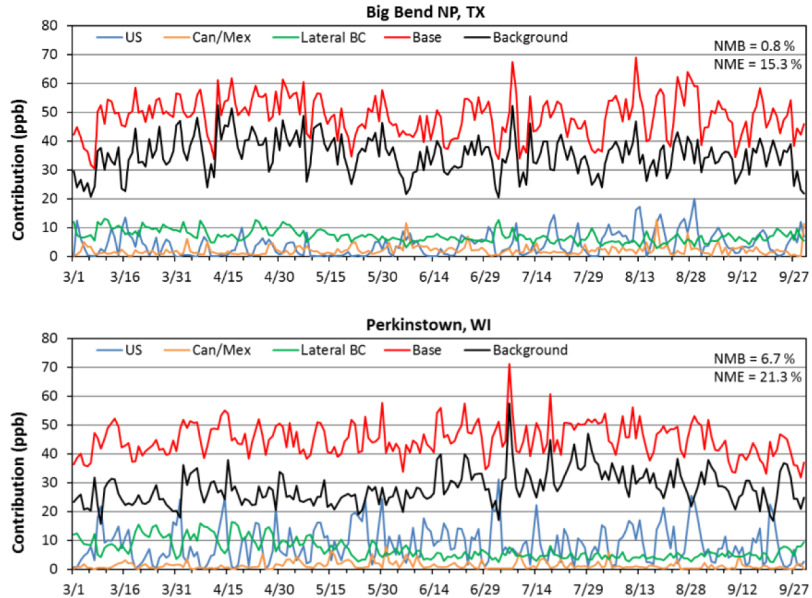

Figure 11. Anthropogenic contributions to $\mathrm{MDA} 8 \mathrm{O}_{3}$ at selected AQS and CASTNet sites along with base-case and background concentrations and model performance statistics (no threshold).

Net sites are in Figs. S14 and S15, respectively. The background concentration is $20-40 \mathrm{ppb}$ at Cleveland and Dallas but generally greater, $30-50 \mathrm{ppb}$, at Denver and Big Bend and a larger fraction of the base-case concentration at the latter sites. At Perkinstown, the background is $20-30 \mathrm{ppb}$ in spring but greater in July and August, including a peak of $58 \mathrm{ppb}$ on 6 July. The contribution from the lateral BCs is generally larger in spring $(5-15 \mathrm{ppb})$ than in summer $(\leq 5 \mathrm{ppb})$. At Cleveland, Dallas, and Perkinstown, the larger MDA8 $\mathrm{O}_{3}$ concentrations in the base case are driven by the US emissions (except for 6 July at Perkinstown). The US emissions contribute to the base-case concentrations at Denver and Big
Bend during summer but are less important $(<20 \mathrm{ppb})$ than at other sites. The contribution of Canadian/Mexican emissions is largest for Cleveland and Big Bend, with maximum contributions at these sites of 22 and $13 \mathrm{ppb}$, respectively.

There are negative contributions from US anthropogenic emissions on some days in Cleveland, Dallas, and Denver. These are situations in which large $\mathrm{NO}_{x}$ emissions in the base case inhibit $\mathrm{O}_{3}$ formation. The sensitivity of $\mathrm{O}_{3}$ to the emissions is positive at the starting point of the integral in Eq. (1) (background case) but negative at the ending point (base case), and if the emissions are large enough the total integral is negative. The negative contributions, which are small in magnitude, merely indicate that large reductions in the US anthropogenic emissions are necessary on these days before $\mathrm{O}_{3}$ decreases in response.

\section{Conclusions}

We used the CAMx regional model in a one-way nest within the GEOS-Chem global model to predict North American $\mathrm{O}_{3}$ concentrations in March-September 2010 for a base case with all emissions present and a natural-background case without worldwide anthropogenic emissions. The difference between these two simulations, the anthropogenic increment, was allocated to the anthropogenic sources: US emissions, Canadian/Mexican emissions, and the anthropogenic components of the lateral BCs and the top BCs. The PIM was used for this source allocation, which required sensitivities from three additional simulations with emissions and BCs intermediate between the base and background cases. The major unique features of the study are allocating the anthropogenic $\mathrm{O}_{3}$ increment, rather than the total concentration, and estimating contributions of the anthropogenic components of the BCs, rather than the total BCs (Lefohn et al., 2014; Dolwick et al., 2015; Baker et al., 2015; Nopmongcol et al., 2017).

The predicted natural background MDA8 $\mathrm{O}_{3}$ is larger in the western US and Mexico than in the eastern US. The spatial pattern is similar in spring and summer with the exceptions that concentrations are smaller in Mexico and larger in Canada in summer. The largest background $\mathrm{MDA} 8 \mathrm{O}_{3}$ in the US is in the mountainous areas of Colorado, New Mexico, Arizona, and California. For the larger MDA8 $\mathrm{O}_{3}$ concentrations in the base case (T10base average), the background $\mathrm{O}_{3}$ at Denver is $50 \mathrm{ppb}$, which is $69 \%$ of the corresponding base-case concentration ( $72 \mathrm{ppb}$ ). The background $\mathrm{O}_{3}$ exceeds $60 \mathrm{ppb}$ in some other western US locations.

Using the T10base average, the US anthropogenic emissions are the largest contributor in ppb and percent to the anthropogenic $\mathrm{O}_{3}$ increments in the eastern US and California. Second in importance are the contributions of the anthropogenic lateral $\mathrm{BCs}$, which are largest for the higherelevation US sites in the Intermountain West and sites closest to the boundaries. The Canadian/Mexican emissions are third in importance, affecting the northern, east-coast, and 
southwest US and some interior states. The contribution of the anthropogenic top BCs is always very small.

We also examined results for the larger MDA8 $\mathrm{O}_{3}$ in the background case (T10bkgd average). The anthropogenic $\mathrm{O}_{3}$ increment is smaller with the T10bkgd average than the T10base average due to a reduced contribution from US emissions. The contribution of the Canadian/Mexican emissions remains about the same, and the contribution from the lateral $\mathrm{BCs}$ increases by up to $5 \mathrm{ppb}$ at lower-elevation urban sites. The net effect is that the relative importance of the lateral BCs is significantly increased for the days with the largest background concentrations, up to about $70 \%$.

GEOS-Chem may have less stratosphere-troposphere exchange than AM3, which may cause the smaller background $\mathrm{O}_{3}$ concentrations with GEOS-Chem than AM3 found by Fiore et al. (2014) for the western US in spring. Hence, using $\mathrm{BCs}$ from $\mathrm{AM} 3$ for the CAMx simulations may give greater background and base-case $\mathrm{O}_{3}$ at western sites in spring, which could affect the T10bkgd results in Table 3. The T10base results would not be affected because all the days included in the average are in summer except for the Big Bend average, which includes some spring days.

Global and regional models are continuing to evolve as new data and analyses become available. Estimates of lightning $\mathrm{NO}_{x}$ emissions have been reduced in recent studies with GEOS-Chem (Zhang et al., 2014; Travis et al., 2016) from those in the version of GEOS-Chem we used (Zhang et al., 2011). Using satellite data, Pickering et al. (2016) estimated even lower lightning $\mathrm{NO}_{x}$ emissions (per flash) over the Gulf of Mexico than Zhang et al. (2014) and Travis et al. (2016). Such changes would affect the BCs obtained from GEOSChem for the south boundary of our CAMx domain but also the lightning $\mathrm{NO}_{x}$ emissions used in CAMx.

Several recent studies have concluded that the 2011 NEI overestimates US anthropogenic $\mathrm{NO}_{x}$ emissions (Anderson et al., 2014; Goldberg et al., 2016; Souri et al., 2016; Travis et al., 2016). Our CAMx simulations used the 2008 NEI projected to 2010, but the procedures used in developing different versions of the NEI are similar enough that any overestimation of $\mathrm{NO}_{x}$ emissions in the 2011 NEI likely implies overestimation in the $2008 \mathrm{NEI}$ as well. Any overestimation in our inventory would directly cause an overestimate of the source contribution for US anthropogenic emissions. Our GEOS-Chem simulation did not include the changes of Travis et al. (2016), so overestimation in the inventory would also indirectly affect the source contributions via the BCs to the extent that there is recirculation of pollutants from inside the North American domain to the outside and then back.

Other recent work has suggested changes to GEOS-Chem for $\mathrm{O}_{3}$ generation in wildfire plumes (Zhang et al., 2014; $\mathrm{Lu}$ et al., 2016), vertical mixing in the lower troposphere (Travis et al., 2016), and the chemistry (Fisher et al., 2016; Schmidt et al., 2016; Sherwen et al., 2016). Note that adding halogen chemistry decreases the global tropospheric $\mathrm{O}_{3}$ burden in GEOS-Chem by 14-19\% (Schmidt et al., 2016; Sherwen et al., 2016). As some of these proposed modifications are implemented in global and regional models, predictions of the background $\mathrm{O}_{3}$, the anthropogenic increment, and the source contributions to the increment are likely to change.

Data availability. The CAMx model can be obtained at http: //www.camx.com and the GEOS-Chem model at http://www. geos-chem.org. The observed data are available at http:// ds.data.jma.go.jp/gmd/wdcgg/cgi-bin/wdcgg/catalogue.cgi (WMO, 2016) (international surface sites), http://www.esrl.noaa.gov/ gmd/dv/data/index.php (NOAA, 2016b) (ozonesondes), https:// www.epa.gov/castnet (CASTNet sites), and https://www.epa.gov/ aqs (AQS sites). The AQMEII modeling inputs used with CAMx are available to AQMEII participants at http://aqmeii. jrc.ec.europa.eu. The boundary of the US Exclusive Economic Zone used to apportion shipping emissions is available at http://www.nauticalcharts.noaa.gov/csdl/mbound.htm. The land cover and emission factor inputs for the biogenic emissions used with CAMx are available at http://aqrp.ceer.utexas. edu/projectinfoFY14_15/14-016/14-01620Final20Report.zip. The anthropogenic emissions used with GEOS-Chem, other than the VOC emissions, are available at http://edgar.jrc.ec.europa. eu/overview.php?v=42 (European Commission, 2011). The anthropogenic VOC emissions used with GEOS-Chem are available at http://wiki.seas.harvard.edu/geos-chem/images/4/49/GC_ RETRO_update_v831_final.pdf (Reinhart and Millet, 2011). The GEOS-5 meteorological fields for GEOS-Chem are available at http://wiki.seas.harvard.edu/geos-chem/index.php/GEOS-5.

\section{The Supplement related to this article is available online at https://doi.org/10.5194/acp-17-12553-2017- supplement.}

Competing interests. The authors declare that they have no conflict of interest.

Acknowledgements. We thank the Atmospheric Impacts Committee of the Coordinating Research Council for supporting this work and Daniel Jacob, Harvard University, for helpful discussions. We also thank the reviewers for their comments, which improved the paper.

Edited by: Chul Han Song

Reviewed by: two anonymous referees

\section{References}

Anderson, D. C., Loughner, C. P., Diskin, G., Weinheimer, A., Canty, T. P., Salawitch, R. J., Worden, H. M., Fried, A., Mikoviny, T., Wisthaler, A., and Dickerson, R. R.: Measured and modeled CO and NOy in DISCOVER-AQ: An evaluation of emissions and chemistry over the eastern US, Atmos. Environ., 96, 78-87, 2014. 
Baker, K. R., Emery, C., Dolwick, P., and Yarwood, G.: Photochemical grid model estimates of lateral boundary contributions to ozone and particulate matter across the continental United States, Atmos. Environ., 123, 49-62, 2015.

Bey, I., Jacob, D. J., Yantosca, R. M., Logan, J. A., Field, B. D., Fiore, A. M., Li, Q., Liu, H. Y., Mickley, L. J., and Schultz, M. G.: Global modeling of tropospheric chemistry with assimilated meteorology: Model description and evaluation, J. Geophys. Res., 106, 23073-23095, 2001.

Dolwick, P., Akhtar, F., Baker, K. R., Possiel, N., Simon, H., and Tonnesen, G.: Comparison of background ozone estimates over the western United States based on two separate model methodologies, Atmos. Environ., 109, 282-296, 2015.

Donner, L. J., Wyman, B. L., Hemler, R. S., Horowitz, L. W., Ming, Y., Zhao, M., Golaz, J.-C., Ginoux, P., Lin, S. J., Schwarzkopf, M. D., Austin, J., Alaka, G., Cooke, W. F., Delworth, T. L., Freidenreich, S. M., Gordon, C. T., Griffies, S. M., Held, I. M., Hurlin, W. J., Klein, S. A., Knutson, T. R., Langenhorst, A. R., Lee, H.-C., Lin, Y., Magi, B. I., Malyshev, S. L., Milly, P. C. D., Naik, V., Nath, M. J., Pincus, R., Ploshay, J. J., Ramaswamy, V., Seman, C. J., Shevliakova, E., Sirutis, J. J., Stern, W. F., Stouffer, R. J., Wilson, R. J., Winton, M., Wittenberg, A. T., and Zeng, F.: The dynamical core, physical parameterizations, and basic simulation characteristics of the atmospheric component AM3 of the GFDL global coupled model CM3, J. Climate, 24, 3484-3519, 2011.

Dunker, A. M.: The decoupled direct method for calculating sensitivity coefficients in chemical kinetics, J. Chem. Phys., 81, 23852393, 1984.

Dunker, A. M.: Path-integral method for the source apportionment of photochemical pollutants, Geosci. Model Dev., 8, 1763-1773, https://doi.org/10.5194/gmd-8-1763-2015, 2015.

Dunker, A. M., Yarwood, G., and Ortmann, J. P., and Wilson, G. M.: The decoupled direct method for sensitivity analysis in a three dimensional air quality model- implementation, accuracy, and efficiency, Environ. Sci. Technol., 36, 2965-2976, 2002.

Dunker, A. M., Koo, B., and Yarwood, G.: Source apportionment of the anthropogenic increment to ozone, formaldehyde, and nitrogen dioxide by the path-integral method in a 3D model, Environ. Sci. Technol., 49, 6751-6759, 2015.

Emery, C., Jung, J., Downey, N., Johnson, J., Jimenez, M., Yarwood, G., and Morris, R.: Regional and global modeling estimates of policy-relevant background ozone over the United States, Atmos. Environ., 47, 206-217, 2012.

Emery, C., Tai, E., Yarwood, G., and Lin, M.: Using Global and Regional Models to Represent Background Ozone Entering Texas, Texas Air Quality Research Program Project 12-011, University of Texas, Austin, TX, Environ International, Novato, CA, available at: http://aqrp.ceer.utexas.edu/projectinfoFY12_13/12-011/ 12-011\%20Final\%20Report.pdf (last access: 24 October 2016), 2013.

European Commission: Emissions Database for Global Atmospheric Research, available at: http://edgar.jrc.ec.europa.eu/ overview.php?v=42 (last access: 8 November 2016), 2011.

Fiore, A. M., Oberman, J. T., Lin, M. Y., Zhang, L., Clifton, O. E., Jacob, D. J., Naik, V., Horowitz, L. W., Pinto, J. P., and Milly, G. P.: Estimating North American background ozone in US surface air with two independent global models: Variability, uncer- tainties, and recommendations, Atmos. Environ., 96, 284-300, 2014.

Fisher, J. A., Jacob, D. J., Travis, K. R., Kim, P. S., Marais, E. A., Chan Miller, C., Yu, K., Zhu, L., Yantosca, R. M., Sulprizio, M. P., Mao, J., Wennberg, P. O., Crounse, J. D., Teng, A. P., Nguyen, T. B., St. Clair, J. M., Cohen, R. C., Romer, P., Nault, B. A., Wooldridge, P. J., Jimenez, J. L., CampuzanoJost, P., Day, D. A., Hu, W., Shepson, P. B., Xiong, F., Blake, D. R., Goldstein, A. H., Misztal, P. K., Hanisco, T. F., Wolfe, G. M., Ryerson, T. B., Wisthaler, A., and Mikoviny, T.: Organic nitrate chemistry and its implications for nitrogen budgets in an isoprene- and monoterpene-rich atmosphere: constraints from aircraft $\left(\mathrm{SEAC}^{4} \mathrm{RS}\right)$ and ground-based (SOAS) observations in the Southeast US, Atmos. Chem. Phys., 16, 5969-5991, https://doi.org/10.5194/acp-16-5969-2016, 2016.

Giglio, L., Randerson, J. T., van der Werf, G. R., Kasibhatla, P. S., Collatz, G. J., Morton, D. C., and DeFries, R. S.: Assessing variability and long-term trends in burned area by merging multiple satellite fire products, Biogeosciences, 7, 1171-1186, https://doi.org/10.5194/bg-7-1171-2010, 2010.

Global Modeling and Assimilation Office (GMAO), NASA Goddard Space Flight Center: GEOS-5.2.0, available at: http://wiki. seas.harvard.edu/geos-chem/index.php/GEOS-5 (last access: 8 November 2016), 2013.

Goldberg, D. L., Vinciguerra, T. P., Anderson, D. C., Hembeck, L., Canty, T. P., Ehrman, S. H., Martins, D. K., Stauffer, R. M., Thompson, A. M., Salawitch, R. J., and Dickerson, R. R.: CAMx ozone source attribution in the eastern United States using guidance from observations during DISCOVER-AQ Maryland, Geophys. Res. Lett., 43, 2249-2258, 2016.

Guenther, A., Karl, T., Harley, P., Wiedinmyer, C., Palmer, P. I., and Geron, C.: Estimates of global terrestrial isoprene emissions using MEGAN (Model of Emissions of Gases and Aerosols from Nature), Atmos. Chem. Phys., 6, 3181-3210, https://doi.org/10.5194/acp-6-3181-2006, 2006.

Hudman, R. C., Moore, N. E., Mebust, A. K., Martin, R. V., Russell, A. R., Valin, L. C., and Cohen, R. C.: Steps towards a mechanistic model of global soil nitric oxide emissions: implementation and space based-constraints, Atmos. Chem. Phys., 12, 7779-7795, https://doi.org/10.5194/acp-12-7779-2012, 2012.

Jiang, Z., Worden, J. R., Payne, V. H., Zhu, L., Fischer, E., Walker, T., and Jones, D. B. A.: Ozone export from East Asia: the role of PAN, J. Geophys. Res., 121, 6555-6563, 2016.

Koo, B., Chien, C.-J., Tonnesen, G., Morris, R., Johnson, J., Sakulyanontvittaya, T., Piyachaturawat, P., and Yarwood, G.: Natural emissions for regional modeling of background ozone and particulate matter and impacts on emissions control strategies, Atmos. Environ., 44, 2372-2382, 2010.

Lefohn, A. S., Emery, C., Shadwick, D., Wernli, H., Jung, J., and Oltmans, S. J.: Estimates of background surface ozone concentrations in the United States based on model-derived source apportionment, Atmos. Environ., 84, 275-288, 2014.

Lin, M., Fiore, A. M., Cooper, O. R., Horowitz, L. W., Langford, A., Levy, H., Johnson, B. J., Naik, V., Oltmans, S. J., and Senff, C. J.: Springtime high surface ozone events over the western United States: Quantifying the role of stratospheric intrusions, J. Geophys. Res., 117, D00V22, https://doi.org/10.1029/2012jd018151, 2012. 
Lin, M., Horowitz, L. W., Payton, R., Fiore, A. M., and Tonnesen, G.: US surface ozone trends and extremes from 1980 to 2014 : quantifying the roles of rising Asian emissions, domestic controls, wildfires, and climate, Atmos. Chem. Phys., 17, 29432970, https://doi.org/10.5194/acp-17-2943-2017, 2017.

Lu, X., Zhang, L., Yue, X., Zhang, J., Jaffe, D. A., Stohl, A., Zhao, Y., and Shao, J.: Wildfire influences on the variability and trend of summer surface ozone in the mountainous western United States, Atmos. Chem. Phys., 16, 14687-14702, https://doi.org/10.5194/acp-16-14687-2016, 2016.

Mathews, J. H. and Fink, K. K.: Numerical Methods Using Matlab, Fourth Edition, Prentice Hall, Upper Saddle River, New Jersey, USA, 2004.

McDonald-Buller, E. C., Allen, D. T., Brown, N., Jacob, D. J., Jaffe, D., Kolb, C. E., Lefohn, A. S., Oltmans, S., Parrish, D. D., Yarwood, G., and Zhang, L.: Establishing policy relevant background (PRB) ozone concentrations in the United States, Environ. Sci. Technol., 45, 9484-9497, 2011.

Morris, R., Emery, C., and Johnson, J.: Sea Salt and Lightning Emissions, Technical Memorandum prepared for the Western Regional Air Partnership, Environ International, Novato, CA, http://www.wrapair2.org/pdf/memo_12_seasalt_lightning_ june25_2012_final.pdf (last access: 23 December 2016), 2012.

Murray, L. T., Jacob, D. J., Logan, J. A., Hudman, R. C., and Koshak, W. J.: Optimized regional and interannual variability of lightning in a global chemical transport model constrained by LIS/OTD satellite data, J. Geophys. Res.-Atmos., 117, D20307, https://doi.org/10.1029/2012JD017934, 2012.

National Oceanic and Atmospheric Administration (NOAA), Office of Coast Survey: U.S. Maritime Limits and Boundaries, available at: http://www.nauticalcharts.noaa.gov/csdl/mbound. htm, last access: 29 December 2016a.

National Oceanic and Atmospheric Administration (NOAA), Earth System Research Laboratory (ESRL), Global Monitoring Division (GMD), available at: http://www.esrl.noaa.gov/gmd/dv/ data/index.php, last access: 15 June 2016b.

Nopmongcol, U., Jung, J., Kumar, N., and Yarwood, G.: Changes in US background ozone due to global anthropogenic emissions from 1970 to 2020, Atmos. Environ., 140, 446-455, 2016.

Nopmongcol, U., Liu, Z., Stoeckenius, T., and Yarwood, G.: Modeling intercontinental transport of ozone in North America with CAMx for the Air Quality Model Evaluation International Initiative (AQMEII) Phase 3, Atmos. Chem. Phys., 17, 9931-9943, https://doi.org/10.5194/acp-17-9931-2017, 2017.

Parrish, D. D., Law, K. S., Staehelin, J., Derwent, R., Cooper, O. R., Tanimoto, H., Volz-Thomas, A., Gilge, S., Scheel, H.-E., Steinbacher, M., and Chan, E.: Long-term changes in lower tropospheric baseline ozone concentrations at northern mid-latitudes, Atmos. Chem. Phys., 12, 11485-11504, https://doi.org/10.5194/acp-12-11485-2012, 2012.

Pickering, K. E., Bucsela, E., Allen, D., Ring, A., Holzworth, R., and Krotkov, N.: Estimates of lightning $\mathrm{NO}_{x}$ production based on $\mathrm{OMI} \mathrm{NO}_{2}$ observations over the Gulf of Mexico, J. Geophys. Res., 121, 8668-8691, 2016.

Pouliot, G., Denier van der Gon, H. A. C., Kuenen, J., Zhang, J., Moran, M. D., and Makar, P. A.: Analysis of the emission inventories and model-ready emission datasets of Europe and North America for phase 2 of the AQMEII project, Atmos. Environ., 115, 345-360, 2015.
Ramboll-Environ: User's Guide, Comprehensive Air Quality Model with Extensions (CAMx), version 6.30, available at: http://www. camx.com/files/camxusersguide_v6-30.pdf, last access: 2 December 2016.

Reinhart, W. and Millet, D.: Implementation of the RETRO Anthropogenic Emission Inventory into the GEOS-Chem Model, University of Minnesota, Minneapolis, MN, available at: http://wiki.seas.harvard.edu/geos-chem/images/4/49/GC_ RETRO_update_v831_final.pdf (last access: 8 November 2016), 2011.

Schmidt, J. A., Jacob, D. J., Horowitz, H. M., Hu, L., Sherwen, T., Evans, M. J., Liang, Q., Suleiman, R. M., Oram, D. E., Le Breton, M., Percival, C. J., Wang, S., Dix, B., and Volkamer, R.: Modeling the observed tropospheric $\mathrm{BrO}$ background: Importance of multiphase chemistry and implications for ozone, $\mathrm{OH}$ and mercury, J. Geophys. Res., 121, 11819-11835, 2016.

Seidel, D. and Randel, W. J.: Variability and trends in the global tropopause estimated from radiosonde data, J. Geophys. Res., 111, D21101, https://doi.org/10.1029/2006JD007363, 2006.

Sherwen, T., Schmidt, J. A., Evans, M. J., Carpenter, L. J., Großmann, K., Eastham, S. D., Jacob, D. J., Dix, B., Koenig, T. K., Sinreich, R., Ortega, I., Volkamer, R., Saiz-Lopez, A., PradosRoman, C., Mahajan, A. S., and Ordóñez, C.: Global impacts of tropospheric halogens $(\mathrm{Cl}, \mathrm{Br}, \mathrm{I})$ on oxidants and composition in GEOS-Chem, Atmos. Chem. Phys., 16, 12239-12271, https://doi.org/10.5194/acp-16-12239-2016, 2016.

Skamarock, W. C., Klemp, J. B., Dudhia, J., Gill, D. O., Barker, D. M., Duda, M. G., Huang, X.-Y., Wang, W., and Powers, J. G.: A Description of the Advanced Research WRF Version 3, NCAR/TN-475+STR, Mesoscale and Microscale Meteorology Division, National Center for Atmospheric Research, Boulder, CO, available at: http://www2.mmm.ucar.edu/wrf/users/docs/ arw_v3.pdf, http://www.wrf-model.org/ (last access: 23 December 2016), 2008

Souri, A. H., Choi, Y., Jeon, W., Li, X., Pan, S., Diao, L., and Westenbarger, D. A.: Constraining $\mathrm{NO}_{x}$ emissions using satellite $\mathrm{NO}_{2}$ measurements during 2013 DISCOVER-AQ Texas campaign, Atmos. Environ., 131, 371-381, 2016.

Travis, K. R., Jacob, D. J., Fisher, J. A., Kim, P. S., Marais, E. A., Zhu, L., Yu, K., Miller, C. C., Yantosca, R. M., Sulprizio, M. P., Thompson, A. M., Wennberg, P. O., Crounse, J. D., St. Clair, J. M., Cohen, R. C., Laughner, J. L., Dibb, J. E., Hall, S. R., Ullmann, K., Wolfe, G. M., Pollack, I. B., Peischl, J., Neuman, J. A., and Zhou, X.: Why do models overestimate surface ozone in the Southeast United States?, Atmos. Chem. Phys., 16, 1356113577, https://doi.org/10.5194/acp-16-13561-2016, 2016.

US Environmental Protection Agency (US EPA): National Emissions Inventory 2008, available at: https://www.epa.gov/air-emissions-inventories/ 2008-national-emissions-inventory-nei-documentation-draft (last access: 30 November 2016), 2013.

US Environmental Protection Agency (US EPA): Clean Air Status and Trends Network (CASTNet), available at: http://www.epa. gov/castnet, last access: 12 December 2016a.

US Environmental Protection Agency (US EPA): Air Quality System (AQS), available at: http://www.epa.gov/aqs, last access: 12 December 2016 b.

US Environmental Protection Agency (US EPA): Air Quality - National Summary, available at: www.epa.gov/air-trends/ 
air-quality-national-summary\#emissions-trends, last access 19 July 2017.

World Meteorological Organization (WMO), Global Atmosphere Watch (GAW): World Data Centre for Greenhouse Gases (WDCGG), available at: http://ds.data.jma.go.jp/gmd/wdcgg/cgi-bin/ wdcgg/catalogue.cgi, last access: 6 July 2016.

Yan, Y., Lin, J., Chen, J., and Hu, L.: Improved simulation of tropospheric ozone by a global-multi-regional two-way coupling model system, Atmos. Chem. Phys., 16, 2381-2400, https://doi.org/10.5194/acp-16-2381-2016, 2016.

Yang, Y.-J., Wilkinson, J. G., and Russell, A. G.: Fast, direct sensitivity analysis of multidimensional photochemical models, Environ. Sci. Technol., 31, 2859-2868, 1997.

Yarwood, G., Morris, R. E., Yocke, M. A., Hogo, H., and Chico, T.: Development of a Methodology for Source Apportionment of Ozone Concentration Estimates from a Photochemical Grid Model, 89th Air and Waste Management Association Annual Meeting, Nashville TN, 23-28 June 1996.

Yarwood, G., Rao, S., Yocke, M., and Whitten, G. Z.: Updates to the Carbon Bond Chemical Mechanism: CB05, Final Report prepared for US EPA, Environ International, Novato, CA, available at: http://www.camx.com/publ/pdfs/CB05_Final_ Report_120805.pdf, last access: 23 December 2016, 2005.

Yu, H., Guenther, A., Warneke, C., de Gouw, J., KemballCook, S., Jung, J., Johnson, J., Liu, Z., and Yarwood, G.: Improved Land Cover and Emission Factor Inputs for Estimating Biogenic Isoprene and Monoterpene Emissions for Texas Air Quality Simulations, Texas Air Quality Research Program Project 14-016, Pacific Northwest National Laboratory, Richland, WA, NOAA Earth System Research Laboratory, Boulder, CO, Ramboll Environ Novato, CA, available at: http://aqrp.ceer.utexas.edu/projectinfoFY14_15/14-016/ 14-016\%20Final\%20Report.zip (last access: 16 November 2016), 2015.
Zhang, L., Jacob, D. J., Boersma, K. F., Jaffe, D. A., Olson, J. R., Bowman, K. W., Worden, J. R., Thompson, A. M., Avery, M. A., Cohen, R. C., Dibb, J. E., Flock, F. M., Fuelberg, H. E., Huey, L. G., McMillan, W. W., Singh, H. B., and Weinheimer, A. J.: Transpacific transport of ozone pollution and the effect of recent Asian emission increases on air quality in North America: an integrated analysis using satellite, aircraft, ozonesonde, and surface observations, Atmos. Chem. Phys., 8, 6117-6136, https://doi.org/10.5194/acp-8-6117-2008, 2008.

Zhang, L., Jacob, D. J., Downey, N. V., Wood, D. A., Blewitt, D. Carouge, C. C., van Donkelaar, A., Jones, D. B. A., Murray, L. T., and Wang, Y.: Improved estimate of the policy-relevant background ozone in the United States using the GEOS-Chem global model with $1 / 2^{\circ} \times 2 / 3^{\circ}$ horizontal resolution over North America, Atmos. Environ., 45, 6769-6776, 2011.

Zhang, L., Jacob, D. J., Yue, X., Downey, N. V., Wood, D. A., and Blewitt, D.: Sources contributing to background surface ozone in the US Intermountain West, Atmos. Chem. Phys., 14, 52955309, https://doi.org/10.5194/acp-14-5295-2014, 2014. 